\title{
Retinoic Acid, Leaky Gut, and Autoimmune Diseases
}

\author{
Leila Abdelhamid and Xin M. Luo * \\ Department of Biomedical Sciences and Pathobiology, College of Veterinary Medicine, Virginia Tech, Blacksburg, \\ VA 24061, USA; leila88@vt.edu \\ * Correspondence: xinluo@vt.edu
}

Received: 12 June 2018; Accepted: 27 July 2018; Published: 3 August 2018

\begin{abstract}
A leaky gut has been observed in a number of autoimmune diseases including type 1 diabetes, multiple sclerosis, inflammatory bowel disease, and systemic lupus erythematosus. Previous studies from our laboratory have shown that lupus mice also bear a leaky gut and that the intestinal barrier function can be enhanced by gut colonization of probiotics such as Lactobacillus spp. Retinoic acid (RA) can increase the relative abundance of Lactobacillus spp. in the gut. Interestingly, RA has also been shown to strengthen the barrier function of epithelial cells in vitro and in the absence of probiotic bacteria. These reports bring up an interesting question of whether RA exerts protective effects on the intestinal barrier directly or through regulating the microbiota colonization. In this review, we will discuss the roles of RA in immunomodulation, recent literature on the involvement of a leaky gut in different autoimmune diseases, and how RA shapes the outcomes of these diseases.
\end{abstract}

Keywords: retinoic acid; leaky gut; autoimmune diseases

\section{Retinoic Acid and Its Signaling}

Retinoic acid (RA) is a multifunctional metabolite of vitamin A that has been known as the maestro behind various functions of vitamin A [1]. RA has three natural isomers including 9-cis, 13-cis, and all-trans RA that have shown different capacities for modulating cellular differentiation and proliferation [2-4]. The different abilities of these isomers to regulate cellular growth and differentiation could be attributed to their different affinities to their nuclear receptors, namely, RA receptors (RARs) and retinoid $X$ receptors (RXRs), that in turn derive selective functionalities as previously reviewed [4]. For instance, all-trans RA binds only to RARs and can induce RXR activation indirectly though isomerization with 9-cis RA, which possesses the affinity to both RARs and RXRs [5].

All-trans RA (hereafter referred to as RA) has been recognized for its immunomodulatory capacities [6,7], but many functional controversies exist where the mechanisms of RA actions remain uncovered. The advancement of scientific technologies such as cloning, sequencing, and proteomic analysis has unraveled the molecular mechanisms behind RA-induced immunomodulation. Knowledge relating to the discovery of retinoid receptors and the rising themes on their mechanisms of action have been reviewed elsewhere [8]. However, how the binding of RA with its receptors may induce different functions is still an active area of research. Here, we briefly review RA signaling through binding to different $\operatorname{RAR}$ isotypes $(\operatorname{RAR} \alpha, \beta, \gamma)$ that work selectively via heterodimerization with RXRs [9]. RXRs are known to heterodimerize with other nuclear receptors such as vitamin D receptors [10]. Binding of RA to RAR subtypes induces the formation of heterodimer complexes with RXRs and subsequently regulates various biological activities and cellular fate decisions [11]. Generally, nuclear hormone receptor ligands like RA could modulate cellular gene expression through direct modulation of transcription via binding to specific genes promoters and/or indirectly though nongenomic extranuclear pathways [12]. RAR-RXR dimerization directly induces their binding to specific DNA sequences known as RA response elements (RARE) [13], subsequently promoting and 
regulating a complex niche of genes that induce differentiation of cells into functionally distinct phenotypes [8].

Activation of different RAR isoforms initiates variable and even paradoxical outcomes in different cellular contexts [14,15]. Indeed, along with other factors, including cellular growth factors and cytokine regulation in different cell types, a strictly regulated RA-RAR interaction is needed for sustaining homeostasis. Dysregulation of such integrity can shift from a steady state to diseases [16]. For instance, the ability of RA to induce neutrophil lineage differentiation from common hematopoietic progenitors is controlled by its ligation to RAR $\alpha$. Consequently, the perturbation in RA-RAR $\alpha$ ligation has been proposed to contribute to neutrophil-associated leukemic phenotypes [17,18]. In addition, the ligation of RA to different nuclear receptors controls both cellular apoptotic and survival signals. For instance, the shifting of RA from binding to the ordinary RARs to binding to the orphan PPAR $\beta / \delta$ receptors hinders the ability of RA to control cellular growth and increases the expression of prosurvival genes leading to cellular hyperplasia [14]. Therefore, the functions of RA differ by ligating to distinct RAR variants as well as by the interaction of RARs with different coregulators (coactivators or corepressors) [19].

In addition to direct genomic transcriptional regulation, RA can initiate the crosstalk between genomic- and nongenomic-driven cellular modulation [20]. Through non-transcriptional mechanisms, RA-RAR ligation regulates multiple extranuclear activation cascades, including mitogen-activated protein kinase (MAPKs) and others. The RA-mediated activation of different kinase cascades is driven by phosphorylation of RAR subtypes. This initiates kinase integration into the cell nucleus, allowing their binding to specific gene promoters and subsequently modulating cell differentiation [21]. Through this mechanism, RA is involved in the regulation of different kinases affecting the cell cycle machinery and the functional differentiation of normal immune cells, including B lymphocytes [22,23], T lymphocytes [24], and natural killer-T (NKT) cells [25]. Therefore, the immunomodulatory capacities of RA to regulate cellular fates and functions is strictly regulated by RA-RAR signaling and dependent on the microenvironment.

Indeed, the interplay between RARs, cytokines, and kinases can explain some mysteries that regulate cellular fates and functions. For example, RAR $\gamma$ has been recently found to mediate cellular life-to-death switch signals by modulating the tumor necrosis factor (TNF)-induced inflammatory versus apoptotic shifts [26]. The release of RAR $\gamma$ into the cytoplasm in the absence of cellular inhibitor of apoptosis (cIAP) induces the dissociation of receptor-interacting protein kinase 1 (RIP1) from the TNF receptor and subsequently initiates the formation of cytoplasmic death complexes, therefore shifting from TNF-induced inflammatory signals to TNF-RIP1-induced apoptosis [26].

Furthermore, previous reviews have shown the roles of RA as a pleiotropic modulator of immune cells to maintain homeostasis especially in intestinal compartments [7]. For instance, how RA-RAR signaling affects both immunogenic and/or tolerogenic responses of different immune cells including antigen presenting cells (APCs, such as dendritic cells (DCs)) and the Thelper-17 (Th17)-T regulatory (Treg) cell axis has been previously discussed [27]. This depends not only on the type of RAR isoforms but also the dose of RA and the affected cell types and can trigger different and sometimes unpredictable outcomes. Similarly, Czarnewski and colleagues recently reviewed the RA-induced modulation of intestinal innate cells, including DCs and innate lymphoid cells (ILCs) [28].

Therefore, in this review, we further expand the discussion on how RA and RARs influence different immune cells, including B lymphocytes, T lymphocytes, and myeloid cells, and how this modulation could vary depending on the cellular developmental stage and the milieu.

\section{Roles of RA on Immunity}

RA effectively contributes to immunity through its intricate crosstalk with different immune elements. RA signaling drives different cell lineage decisions as well as the function of effector immune cells in different contexts. 


\subsection{RA and B Lymphocytes}

B lymphocytes are important regulators of the immune system, for which their effector functions include immunoglobulin (Ig) production for antigen (Ag) neutralization, control of optimal immunization responses, and Ag recognition and presentation to stimulate other effector cells. B-cell dysregulation has been linked to various autoimmune inflammatory conditions [29], and many reports have shown their potent regulation of autoimmunity [30,31].

Different studies have investigated the effect of RA on B-cell development, maturation, and functions. RA selectively promotes B-cell lymphopoiesis in the bone marrow (BM) through RAR $\gamma$ signaling in Nestin (a regulator of lymphopoiesis)-expressing hematopoietic cells [32]. In addition, RA is proposed to create a microenvironment that encourages functional differentiation of $B$ cells $[33,34]$. For instance, the induction of regulatory immunosuppressive B cells (Breg cells) that have protective capacities under many autoimmune conditions largely depends on RA. The ability of tolerogenic DCs to induce $\mathrm{CD} 19^{+} \mathrm{CD} 24^{+} \mathrm{CD} 38^{+}$Breg cells depends on production of RA from DCs and the expression of RARs in the $\mathrm{CD} 19^{+} \mathrm{CD} 24^{+} \mathrm{CD} 38^{+}$population. In vitro treatment of $\mathrm{B}$ cell-DC cocultures with ER50891, a pan-RAR antagonist, hindered the induction of Breg cells [35]. This finding indicates the significance of RA responsiveness for the immune regulation directed by $B$ lymphocytes.

The crosstalk between RA and B cells is necessary for the optimal adaptive responses of B cells in maintaining immune homeostasis. RA has been found to be critical for the humoral T-independent responses of B-cells. Altered levels of IgM and IgG3 and reduction of the functionally developed antibody-secreting cells have been observed with the silencing of RAR $\alpha$ expression in a murine model overexpressing dominant-negative $\operatorname{RAR} \alpha(\operatorname{dnRAR} \alpha)$ [36]. Similarly, RAR $\alpha$ signaling is essential for the isotype switching of antigen-specific $B$ cells to IgA-secreting cells. Loss of RA responsiveness in the CD19 ${ }^{\mathrm{Cre}}$-dnRAR $\alpha$ model has been linked to reduced IgA-secreting cells both in vitro and in vivo. Additionally, RAR $\alpha$-silenced cells exhibit reduced expression of the gut-homing integrin $\alpha 4 \beta 7$, indicating the effect of RA on B-cell migration as well [37].

However, RA affects the isotype switching and homing capacities of only certain subsets of $B$ lymphocytes. At steady states, RA signaling paradoxically promotes IgA-secreting cells with no similar responses on IgG- or IgM-secreting cells. For instance, RAR $\alpha$ agonists can increase IgA levels that are diminished by RAR $\alpha$ antagonist-induced blockade; however, neither the agonist nor the antagonist of RAR $\alpha$ affects the production of other Ig isotypes [38]. Similarly, the intrinsic propensity of RA in modulating the B-cell response is not equal towards all B-cell subsets; instead, the homing and secretory functions of some B cells are more prominently affected. RA has been found to mostly influence the IgA and $\alpha 4 \beta 7$ expression capacities of murine peritoneal B1b cells rather than other peritoneal or splenic B cell populations such as B1a and B2 cells [39]. These findings have been confirmed by different reports that tested RA-induced class switching of B cells in the presence of an activator for B2 cells, such as the mucosal glycoprotein lactoferrin (LF). LF treatment is reported to influence IgA and IgG production by B1 and B2 cells, respectively [40]. Interestingly, even with LF-RA combination treatment, the IgA class-switching and the homing capacities-as indicated by enhanced $\alpha 4 \beta 7$ and chemokine receptor CCR9 expression-were only restricted to B1 cells [41], confirming the paradoxically selective action of RA on certain B-cell subsets.

However, in contrast to the RA-mediated preference of B-cell switching to IgA-producing cells, RA can also mediate polyclonal differentiation of $B$ lymphocytes upon sensing the microenvironment under pathogenic conditions through triggering toll-like receptor 9 (TLR9) and CD180 antigen (TLR homolog leucine-rich repeat 105) [42]. RA has been shown to normalize the proliferation of defective B cells and restore their IgG-producing capacities as well as IL-10 production in the presence of TLR9/CD180 stimulation in common variable immunodeficiency (CVID) models [43]. RA is also known to be able to induce interferon regulatory factor 4 (IRF4) and Blimp1 (a repressor of IFN $\beta$ gene expression); both are plasma cell-generating transcription factors that can promote somatic gene recombination in the variable and conserved regions of the $\mathrm{Ig}$ molecule. This results in class switching with subsequent IgG production in TLR9/CD180-activated human B cells [44]. 
Furthermore, the effects of RA on B-cell responses not only depend on the health conditions (steady state versus pathologic state) but are also cell- and tissue-dependent. For instance, unlike the effect of RA on the gut-homing integrin $\alpha 4 \beta 7$ expression in murine proteneal B1 cells, RA does not influence this integrin expression in other B cell subsets in other tissues such as the splenic marginal zone (MZ) B cells. In contrast, the blockade of RAR $\alpha$ signaling in the dnRAR $\alpha$ model as previously discussed drastically reduced the homing receptor Sphingosine-1-phosphate receptor-1 (S1P1) expression on MZ B cells with no effect on integrin $\alpha 4 \beta 7$ expression [36]. These data further highlight the complex interplay between RA and B cells to induce immune regulation in normal versus sensitized conditions in a tissue- and cell-specific manner.

\subsection{RA and $T$ Lymphocytes}

It is well established that RA is essential in maintaining gut-tropic regulatory $\mathrm{T}$ (Treg) cell responses and the balance between immunity and oral tolerance [45]. RA reciprocally regulates $\mathrm{T}$ helper 17 (Th17) and Treg cells to maintain immune homeostasis [7]. Under normal conditions, RA favors Treg cells over Th1/Th17 differentiation and controls the differentiation [46,47], the homing, and the functional capacities of Treg cells $[48,49]$.

The interplay between RA and different mediators, such as transforming growth factor $\beta$ (TGF $\beta$ ) [50], interleukin 2 (IL-2) [51], and IL-1 family of inflammatory cytokines [52,53], could drive the Treg-Th17 balance. Here, we will discuss the RA-induced regulation of different T-cell subsets, including $\mathrm{CD}^{+}, \mathrm{CD}^{+}$, and $\gamma \delta \mathrm{T}$ cells, meditated by RAR signaling.

Interestingly, as for B cells, the effect of RA on T lymphopoiesis depends selectively on RAR $\gamma$ signaling. Whether RAR $\gamma$ mediates thymic single positive (SP) $\mathrm{CD}^{+}$or $\mathrm{CD} 8^{+} \mathrm{T}$ cells' differentiation lineage specificity is unclear. However, knocking down RAR $\gamma$ in Nestin-expressing thymic cells reduces the thymic double negative (DN) T-cell precursors, as well as $\mathrm{CD}^{+} \mathrm{T}$ cells, immature SP $\mathrm{CD}^{+}$cells, and $\mathrm{CD} 4^{+} \mathrm{CD} 8^{+}$double positive (DP) T cells in the peripheral circulation [32]. Interestingly, RA treatment could reverse the effects of RAR $\gamma$ depletion. Thus, the crosstalk between RA and the thymic microenvironment may govern $\mathrm{CD}^{+}$or $\mathrm{CD} 8^{+} \mathrm{T}$-cell differentiation capabilities.

Among different RAR isoforms, RAR $\alpha$ is proposed to be the most important for RA-directed modulation of T-cell responses. Even though no prominent difference in $\mathrm{CD} 4^{+} \mathrm{T}$-cell numbers was observed with deletion of different RAR isoforms, RAR $\alpha$ was shown to be essential for CD4 ${ }^{+}$T-cell immunity following both oral infection and immunization [54]. Specific deletion of RAR $\alpha$ in CD4 ${ }^{+}$ $\mathrm{T}$ cells drastically reduced their interferon- $\gamma(\mathrm{IFN} \gamma)$ production and was comparable to vitamin A deficiency (VAD)-induced disruption of T-cell homeostasis (e.g., Treg-Th1/Th17 imbalance) [54]. However, RA promotes either inflammatory (Th1) or tolerogenic (Th2) $\mathrm{CD}^{+} \mathrm{T}$-cell lineages in different contexts. For example, concomitantly with tetanus toxoid (TT) immunization, RA treatment dampened IFN $\gamma$ and IL-12 production and increased IL-4/ IFN $\gamma$ ratios in C57BL/ 6 mice, indicating that RA mediated Th2 over Th1 responses [55]. RAR $\alpha$ signaling also promoted Th2 differentiation under inflammatory conditions. For instance, in trinitrobenzene sulfonic acid (TNBS)-induced murine colitis, RAR $\alpha$ agonist injection skewed the lamina propria $C D 4^{+} \mathrm{T}$ cells toward a Th2 phenotype. RA treatment in this mouse model decreased IFN $\gamma$, IL-2, and TNF production while favoring the production of Th2 cytokines, including IL-4 and IL-10 [56]. On the contrary, in a T-cell transfer colitis model, RA was required for the induction of $\mathrm{CD} 4^{+} \mathrm{T}$-cell differentiation and expansion into the Th1 lineage. Blockade of RAR $\alpha$ responsiveness skewed $\mathrm{CD} 4^{+} \mathrm{T}$-cell differentiation toward IL- $17^{+}$and IL- $17^{+}$Foxp $3^{+} \mathrm{T}$ cells and greatly diminished their capacity to differentiate into IFN $\gamma$-producing Th1 cells, thus collectively interfering with the generation of intestinal inflammation [57]. Additionally, RAR $\alpha$ silencing in the same model has been associated with the inability of colonic CD4 ${ }^{+}$intraepithelial lymphocytes (IELs) to differentiate into cytotoxic T lymphocyte (CTL)-like cells [58]. Those findings indicate variable functions of RA-RAR signaling in $\mathrm{CD} 4^{+} \mathrm{T}$ cells under different contexts.

RAR signaling is similarly significant for $\mathrm{CD}^{+} \mathrm{T}$-cell responses. Similar to its effect on $\mathrm{CD} 4^{+} \mathrm{T}$ cells, RAR $\alpha$ has a potent effect on other RAR isoforms in modulating $\mathrm{CD} 8^{+}$T-cell responses following 
infection. Even though the absence of different RARs did not affect the initial T-cell activation, RAR $\alpha$ was essential for CD8 ${ }^{+}$T-cell survival and their effector functions. The conditional deletion of RAR $\alpha$ in $\mathrm{CD}^{+} \mathrm{T}$ cells reduced IL-2 and IFN $\gamma$ production, gut-homing propensity ( $\alpha 4 \beta 7$ and CCR9 expression), and Ag-specific clonal expansion following Listeria monocytogenes infection [59].

Interestingly, RA-mediated immune homeostasis is not confined to the adaptive compartments. RA can also regulate the interface between innate and adaptive responses. This is done through mediating different functions of $\gamma \delta$ T cells, a less abundant T-cell population that is mostly found within IELs and links between both arms of the immune system [60]. Little is known about the molecular mechanisms on how RA modulates $\gamma \delta$ T-cell responses. However, RA has been reported to diminish the production of inflammatory cytokine IL-17A from $\gamma \delta$ T cells and further their production of the anti-inflammatory cytokine IL-22 [61]. Therefore, RA indirectly diminishes the Th17 response that is a major contributor of autoimmunity, as IL-17A production from $\gamma \delta \mathrm{T}$ cells has been proposed to augment the Th17 response [62]. Moreover, $\gamma \delta \mathrm{T}$ cells have recently been shown to play major roles in initiating excessive autoimmune inflammation [63-65]. Therefore, the effect of RA on $\gamma \delta \mathrm{T}$ cells suggests a promising strategy to attenuate autoimmune conditions such as the central nervous system (CNS) autoimmunity by suppressing IL-17 production [66]. Further studies on the molecular mechanisms behind RA-mediated modulation of $\gamma \delta \mathrm{T}$ cells are warranted and may provide insights and targets for controlling hyper-inflammatory signals.

\subsection{RA and Myeloid Cells}

RA is well established as a pluripotent hematopoietic regulator $[67,68]$. The hematopoietic regulatory capacities of RA are driven through the interaction between RA and its nuclear receptors $\operatorname{RAR} \alpha$ and $\operatorname{RAR} \gamma . \operatorname{RAR} \alpha$ bidirectionally controls granulocytopoiesis by promoting cell differentiation in the presence of RA but inhibiting it in the absence of RA [69]. On the other hand, RAR $\gamma$ hinders hematopoietic stem cell (HSC) differentiation in favor of their self-renewal and proliferation [70]. Recent findings suggest that the expression and activities of both RARs coordinate to derive the differentiation lineages of HSCs, and that this is largely dependent on the bioavailability of RA [71]. Therefore, different doses of RA can determine different cellular lineage specificities.

The dose of RA can determine different myeloid cell (MC) differentiation or functional outcomes as well as different myeloid specificities. For instance, during early monopoiesis, continuous RA treatment promotes the differentiation of common bone marrow progenitor cells (BMPCs) into regulatory MCs. In vitro supplementation of RA in BMPCs in the presence of granulocyte-monocyte colony-stimulating factor (GM-CSF) increases the proliferation of mature regulatory CD11b ${ }^{+}$CD11 $c^{-}$Ly6C ${ }^{\text {low/intermediate }}$ monocytes. This is indicated by enhanced expression of both maturation markers, including CD80, CD86, and MHC-II, as well as the suppressive/inhibitory markers including PD-L1 and PD-L2. On the contrary, different responses were observed for mature CD $11 c^{+}$DCs in the same study, suggesting that the influence of RA varies depending on different developmental stages of MC differentiation [72]. Moreover, RA has been found to improve the differentiation of myeloid-derived suppressive cells (MDSCs), a heterogenous immature population that possesses a significant ability to suppress both innate and adaptive responses through direct modulation of cytotoxic T cells (CTLs) and natural killer (NK) cells [73]. The effect of RA on these cells enhanced the antigen-specific responses in cancer patients [74] in a time-dependent fashion [75]. Together, these findings suggest that during early granulocytopoiesis, RA may enhance the immature MCs to express immunosuppressive/regulatory profiles.

In addition, RA promotes the anti-inflammatory capacities of mature monocytes, consequently dampening tissue inflammation. For instance, RA regulates the TLR sensing of monocytes, where RA treatment of primary human monocytes was associated with downregulated TLR2 expression and reduced TLR2- and TLR4-mediated inflammatory cytokine production [76]. Similarly, for in vitro differentiated human macrophages, RA treatment promoted anti-inflammatory responses, indicated by enhanced GM-CSF, monocyte chemotactic protein-1 (MCP-1), and IL-10 production, while reducing 
IL-6, macrophage inflammatory proteins (MIP)- $1 \alpha$, and MIP-1 $\beta$ following lipopolysaccharide (LPS) stimulation [77]. Furthermore, in an in vitro Bacillus Calmette-Guérin (BCG)-primed human monocyte model, RA inhibited the production of cytokines from stimulated monocytes and diminished their response to microbial restimulation. Mechanistically, RA promoted the histone inhibitory signature H3K9me3 and inhibited the stimulatory signature H3K4me3, thereby downregulating the cytokine response of monocytes upon restimulation [78]. RA is proposed to modulate histone methylation through regulating the expression of methyl transferase SUV39H2. On the contrary, for tissue macrophages, the effect of RA may vary according to their tissue microenvironment (e.g., intestinal versus extraintestinal tissues). For example, silencing of RAR signaling in intestinal macrophages isolated from Crohn's disease patients has been associated with a reduced inflammatory macrophage profile-decreased CD14 and human leukocyte Ag (HLA)-DR expression as well as decreased $\mathrm{TNF} \alpha$ production-indicating that RA responsiveness is essential for TNF $\alpha$-induced inflammatory macrophage responses [79]. Therefore, the uptake of RA and/or its intrinsic production by intestinal macrophages may contribute to the macrophages' role in Crohn's disease pathogenesis [79]. This finding suggests that RA may worsen intestinal inflammation during progressive stages of inflammation through potentiating the macrophages' pro-inflammatory response. In contrast, in an extraintestinal environment, as in the alcoholic liver disease (ALD) model, reduced RA concentration in vivo was correlated with aggravated disease pathogenesis through priming of peritoneal macrophage-mediated inflammatory responses. Consistent with this, RA supplementation decreased the TNF $\alpha$ - and nitric oxide (NO)-induced pro-inflammatory state in peritoneal macrophages [80]. These findings suggest that the RA-mediated regulation of the differentiation and functions of MCs varies depending on cellular developmental stages as well as their surrounding microenvironment under normal versus diseased conditions. This calls for further studies on the mechanisms and influencing factors regulating the interaction between RA and MCs.

\section{Efficacies of RA in the Treatment of Autoimmune Diseases}

Autoimmune diseases are idiopathic multifactorial conditions that have been characterized by the breakdown of self-tolerance. In such cases, the immune system deviates from attacking nonself-invaders to attacking self-tissues, resulting in multiple tissue damages [81]. The roles of RA on autoimmunity could be bidirectional depending on different factors, including the tissue microenvironment and the stage of disease. For instance, supplementation of RA can ameliorate some tissues' pathologies, as in the kidney during lupus nephritis, while deteriorating other tissue pathologies, for instance, the lung and skin lesions [82]. Similarly, RA treatment exacerbates neuroinflammation by increasing autoantibodies, total IgG, and complement C3 protein deposition in the brain tissue and has been associated with more severe neurodegeneration in MRL/lpr mice [83]. Furthermore, with its potential toxicity [84,85], employing RA as a potential therapeutic for autoimmune disorders requires a deeper consideration for the context in which RA interplays. Further research on developing fine-tuned RA-mediated therapies that consider the different RA signaling pathways is necessary to avoid any undesired outcomes, especially for long-term therapies. Here, we highlight efficacies of RA in the treatment of different autoimmune diseases (Figure 1).

\subsection{Type 1 Diabetes}

Type 1 diabetes (T1D), or juvenile diabetes, is an idiopathic condition in which pancreatic islets are destroyed through the autoimmune-mediated destruction of $\beta$ cells that hinders their ability to produce insulin, thus resulting in high blood glucose levels [86]. Ongoing research findings reveal a protective effect of RA against T1D in mice. For instance, RA prevented the onset of T1D even after the establishment of insulitis by suppressing the IFN $\gamma$-producing T cells, upregulating Treg proliferation, and hindering the $\mathrm{CD} 8^{+} \mathrm{T}$-cell infiltration into pancreatic islets, consequently reversing their cytotoxic activities in the nonobese diabetic (NOD) mouse model as well as the adoptive transfer model in $\mathrm{NOD} /$ scid mice [87]. In addition, RAR signaling is essential for continued $\beta$-cell responsiveness to 
glucose and sustaining their insulin production [88]. RA treatment has been shown to interfere with T1D progression and results in the maintenance of blood glucose in Streptozotocin (STZ)-induced T1D. RA supplementation to this mouse model inhibited STZ-induced $\beta$-cell damage, consequently improving the serum insulin levels and enhancing glucose uptake, thus lowering the blood glucose levels. Immunologically, RA reduced the inflammatory IFN $\gamma$ and increased the anti-inflammatory IL-4 levels [89]. Subsequently, RA treatment was able to lessen pancreatic destruction through counteracting with the inflammatory niche-induced damage. However, after the initiation of T1D, RA treatment might not be sufficient to reverse hyperglycemia nor improve the survival rates even when combined with exendin-4, a glucagon-like peptide- 1 receptor agonist that enhances pancreatic $\beta$-cell function [90]. These findings indicate that disease stage-specific modulation of the immune system with RA and RA therapies could be promising preventions but not cures for T1D.

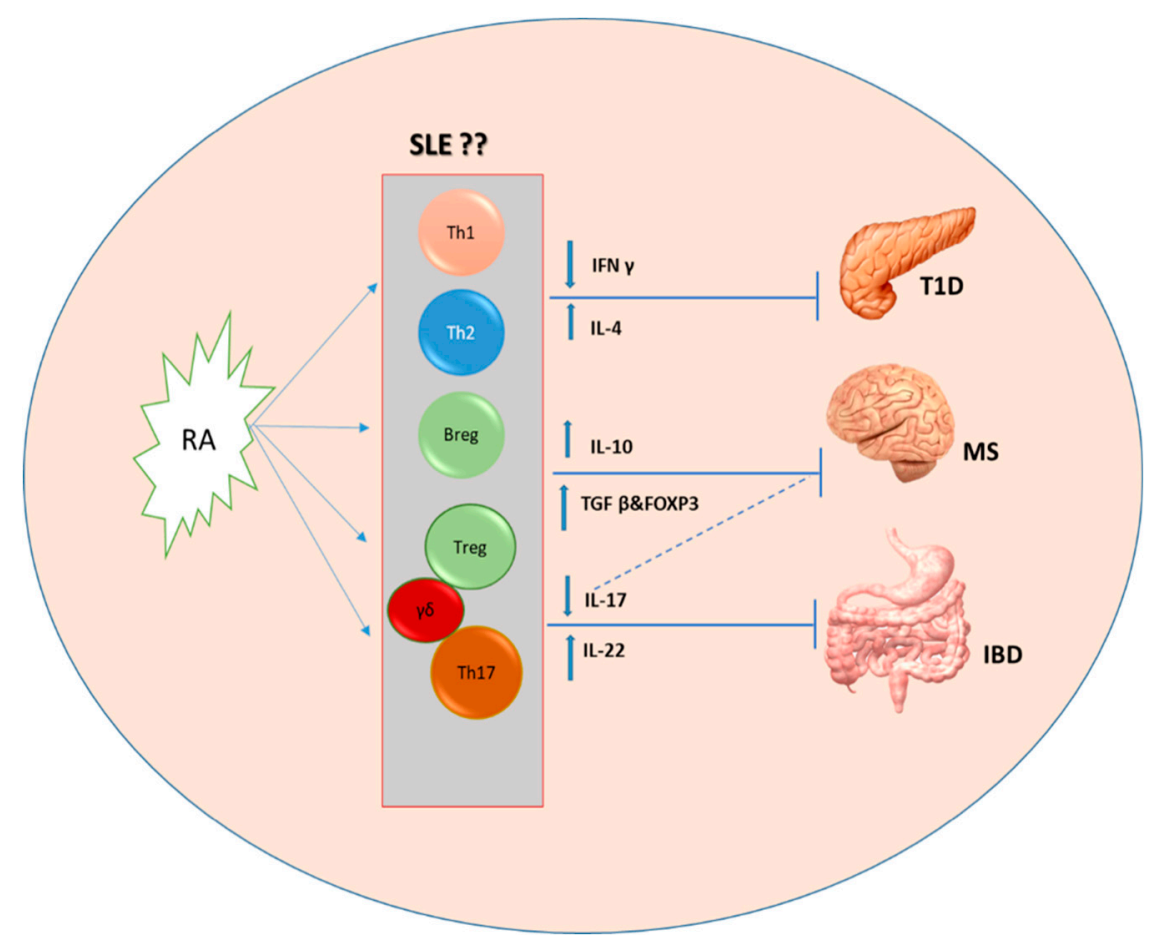

Figure 1. Retinoic acid (RA)-mediated cellular regulation in autoimmune diseases. RA suppresses the inflammatory T helper (Th)1/Th17 responses by decreasing interferon- $\gamma$ (IFN $\gamma$ ) and interleukin (IL)-17. It also primes a regulatory/anti-inflammatory environment by enhancing IL-4, IL-10, IL-22, and transforming growth factor $\beta$ (TGF $\beta$ ). Through these mechanisms, RA may dampen different pathologies, including type 1 diabetes (T1D), multiple sclerosis (MS), and inflammatory bowel disease (IBD). However, the cellular mechanisms of RA in modulating systemic lupus erythematosus (SLE) are yet to be uncovered.

\subsection{Multiple Sclerosis}

Multiple sclerosis (MS) is an autoimmune chronic neuroinflammation that affects the CNS [91]. MS could be a consequence of perturbed microbiota that creates a peripheral inflammatory milieu promoting disease [92,93]. The efficacies of different RA isomers in modulation of MS and its experimental animal model, experimental autoimmune encephalitis (EAE), have been previously reviewed [94]. Here, we further expand on the discussion. In the neuroinflammatory context of MS, RA showed various beneficial effects [95]. In clinical trials, supplementation of RA was not correlated with MS exacerbation [96]. On the contrary, RA enhanced the overall quantitative assessment or MS functional composite of relapsing-remitting MS patients [97]. Moreover, RA treatment reduced fatigue and depression symptoms that often occur with relapsing cases of MS [98]. 
Indeed, vitamin A has been proposed to derive intrinsic immunoregulation within the CNS tissue under the MS condition [99]. RA is intrinsically produced by the reactive astrocytes that exhibit upregulated RALDH2 expression. This endogenously produced RA is linked to improved blood-brain barrier (BBB) function and diminished inflammatory responses as represented by reduced monocyte adhesion and activation in the brain [100].

Additionally, RA has been found to ameliorate the development of MS through improving the humoral and cellular responses. RA modulates B-cell responses [101] and re-establishes the inflammatory versus immunoprotective T-cell balance [102] in MS patients. For instance, RA treatment initiated comparable responses from B cells similar to those obtained with the first line drugs widely used for MS, including glatiramer acetate (GA) and IFN $\beta-1 b$. RA enhanced IL-10 production from TLR-stimulated B cells isolated from RA-treated relapsing MS patients without affecting the inflammatory TNF $\alpha$ [101]. In addition, RA upregulated Foxp3 and TGF $\beta$ gene expression in PBMCs isolated from clinically treated patients, indicating skewed T-cell populations toward Treg responses [102]. Moreover, in the experimental MS model, RA treatment hindered IL-17 production from $\gamma \delta \mathrm{T}$ cells and reduced their infiltration into the CNS. In fact, RA supplementation to $\gamma \delta \mathrm{T}$ cells was correlated with their mitigated ability for disease induction [66]. These findings highlight the potential role of RA in halting MS initiation and progression.

\subsection{Inflammatory Bowel Disease}

Inflammatory bowel disease (IBD) is one of most prevalent autoimmune diseases in the Western and industrialized world [103], where the epidemiological data correlates the Western lifestyle to disease pathogenesis [104]. Indeed, IBD is a multifactorial cycle of mucosal damage and breaching of the balance between luminal antigens and mucosal immunity $[105,106]$.

Regulation of intestinal homeostasis through RA [7] may encourage the utilization of RA-based therapies for controlling the breakdown of intestinal tolerance that could lead to IBD progression [106]. RA may mitigate IBD severity through various immunoregulatory mechanisms. RA could: (1) restore and/or reprogram the impaired Treg/Th17 lineage differentiation that is usually linked to IBD development $[51,107]$ by inducing adaptive Treg cells and imprinting their gut-homing phenotype in response to inflammatory stimuli [108]; (2) modulate the recognition of different TLR ligands and control the activation of downstream transcription factor signaling [109,110]; (3) downregulate inflammatory signaling molecules like nitric oxide (NO) from PBMCs of IBD patients, even after the establishment of the pro-inflammatory niche [111]; (4) regulate the production of immunoregulatory cytokines, such as by enhancing the synthesis of IL-22 by $\gamma \delta \mathrm{T}$ cells and ILCs and consequently attenuating colitis [61]; and (5) synergize with immunoregulatory mediators like TGF $\beta$ for maintaining gut homeostasis [112].

Interestingly, RA has been found to not only mitigate intestinal inflammation but also counteract IBD-related consequences such as necrotizing colitis and tumorigenesis. Altered metabolism of RA was correlated with increased tumor burdens in ulcerative colitis (UC) patients due to inhibition of tumor-clearing CD8 ${ }^{+}$CTLs, whereas RA normalization induced protective CD8 ${ }^{+}$T-cell activities [113]. In addition, blockade of CYP26A1 that restores RA levels in experimental murine IBD models could diminish both intestinal inflammation and tumor development [114]. Moreover, RA treatment has been found to downregulate TNF $\alpha$ and NO synthase 2 (NOS2) levels that are associated with UC and colitis-associated cancer (CAC). Mechanistically, RA was able to dampen TLR4/NF- $\kappa B$ signaling, and this highlights new targets for tackling UC and CAC [115]. Therefore, employing the ability of RA to modulate mucosal immunity may help in controlling IBD and its pathological consequences.

\subsection{Systemic Lupus Erythematosus}

Systemic lupus erythematosus (SLE), or lupus, is a multiorgan autoimmune-driven destruction [116,117]. As a natural metabolite, RA could provide a less risky treatment for SLE, especially when compared to the severe adverse effects of the immunosuppressants such as 
corticosteroids and cyclophosphamide [118,119]. RA treatment has been shown to diminish the severity of lupus nephritis, one of the most prevalent manifestations to SLE in both animal models [120] and clinical trials of lupus patients [119].

Studies have shown various mechanisms through which RA treatment may modulate the course of SLE. For example, RA has been reported to restore the downregulated lactobacilli-a key feature of leaky gut in MRL/lpr mice-thus ameliorating the inflammatory symptoms of lupus [121,122]. In addition, supplementation of RA that restored vitamin A hypovitaminosis in SLE patients re-established the Th17/Treg balance that is often skewed for lupus induction [123]. Moreover, RA interferes with the signaling of transcriptional regulators needed for lupus initiation. For example, RA has been found to inhibit the activities of prolyl isomerase Pin1, a regulator of interleukin-1 receptor-associated kinase 1 (IRAK1) in the TLR7/TLR9 signaling pathway [124]. Similarly, RA can inhibit interferon regulatory factor 7 (IRF-7) signaling, which is associated with deteriorated lupus. Furthermore, in vitro RA supplementation to PBMCs derived from lupus patients was able to suppress IRAK1/IRF-7 signaling [124]. Therefore, RA control of Pin1 activation was able to significantly inhibit lupus initiation and improve the overall phenotypic parameters in both MRL/lpr and B6/lpr lupus-prone mice [124]. Dissecting the underlying mechanisms of action for RA may help the development of more efficient and less risky targets to inhibit lupus initiation in genetically predisposed individuals.

\section{The Leaky Gut and Autoimmune Diseases}

Even though the exact etiology of autoimmune conditions is vague, a leaky gut has been associated with various autoimmune diseases including T1D [125,126], MS [127,128], IBD [129], and SLE [130]. A previous review by Arrieta et al. (2006) discussed the hypothesis that impaired intestinal permeability and the breakdown of barrier functions are correlated with either local or systemic autoimmune inflammation. Experimental evidence was provided to support this hypothesis [131]. Studies from our laboratory have shown the presence of a leaky gut with impairment of intestinal barrier functions in the genetically predisposed lupus-prone MRL/lpr mice [122]. Here, we will discuss the regulation of intestinal barrier function and the potential mechanisms of how a leaky gut can contribute to autoimmune diseases.

\subsection{Regulation of Intestinal Barrier Function}

The intestinal mucosa has a unique physiology that makes it a system of its own. Despite exposure to a tremendous number of external antigens from the food that we consume, the intestinal mucosa tightly regulates the balance between tolerance and immunity. This can be achieved through a complex loop of interaction between the physical and immunological defenses of the gut [132]. The coordination between these defenses can regulate the production of important immune modulators that are necessary for gut immune homeostasis, e.g., the production of secretory IgA that plays a major role in gut immunity [133].

The intestinal mucosa is a strong physical barrier with a monolayer of intestinal epithelial cells (IECs) interconnected by a network of intercellular junction proteins known as tight junctions (TJs). It keeps the spatial segregation between gut microbiome and food-derived antigens in the intestinal lumen and the underlying lamina propria tissues where the immunological barriers exist [134]. This physical defense is achieved through the inner intestinal wall and its mucus coverage. The secretion of mucin by goblet cells forms a protective barrier that traps pathogens and prevents their invasive colonization [135]. Therefore, the breakdown or dysregulation of mucin is often associated with intestinal inflammation [136], and the integrity of the mucus layer helps to maintain a healthy mucosal functionality [137].

The intestinal mucosa is an important regulator of host immunity. For instance, the intestinal mucosa is enriched with different antimicrobial peptides that are secreted from Paneth cells within the intestinal epithelial lining. Such antimicrobial peptides, including cathelicidins and 
defensins, can regulate the intestinal barrier function and mediate immune defenses against bacterial invasion [138]. Furthermore, IECs themselves are known for their ability to regulate the proliferation and functional differentiation of both innate (basophils, ILCs, and macrophages) and adaptive immune cells (naïve CD4 ${ }^{+} \mathrm{T}$ cells and B cells). This capability of IECs to regulate the responses of different immune cells depends largely on the interaction between different cytokines produced by those cells, as previously reviewed [139].

Interestingly, IECs can also sense the microenvironment for microbial invaders and maintain immune integrity and gut homeostasis. IECs can produce both RA and TGF- $\beta$ that prime tolerogenic $\mathrm{CD}_{103}{ }^{+} \mathrm{DC}$ responses in the mucosal interface $[140,141]$ IECs also differentially modulate the recognition signals for commensal versus pathogenic microbes. Such balance is regulated by the interplay of IECs with different components of innate defenses [142] as well as their surrounding microflora [143]. Even though IECs are in continuous contact with a myriad of microbes, they do not simply pass everything they encounter to the resident APCs in the lamina propria to initiate immunological responses. Instead, IECs have sophisticated recognition pathways where pattern recognition receptors (PRRs) on their surface can differently sense and respond to microbial stimuli according to the site of contact with the pathogens. For instance, the PRRs on IECs are either on their apical surface, which leads to tolerance, or basolateral surface, which leads to immunological responses. This distribution allows for microbial sensing by different PRRs to either inhibit or stimulate inflammatory responses. For instance, sensing of the apically distributed TLR9 suppresses the inflammatory NF-kB, whereas basolateral ones activate the NF- $\mathrm{kB}$ signaling. In turn, this specialized recognition can be translated into tolerance to self-microbiome versus the development of immunologic cascades against pathogens [139]. Similarly, the interaction between IECs and their surroundings controls the ability of IECs to enhance healthy functions of the intestinal barrier or provoke intestinal barrier damage with subsequent local and systemic inflammatory cascades. For example, different pathological stimuli may mediate abnormal shedding of IECs, provoking their pathological turnover, which jeopardizes the ability of these cells to maintain a healthy intestinal barrier function. Bacterial endotoxin LPS, as another example, activates excessive TNF production with subsequent TNFR1-induced NF- $\mathrm{BB}$ signaling, leading to excessive apoptosis of the IECs with abnormal shedding. These mechanisms initiate intestinal barrier dysfunction and can trigger hyperreactive inflammation [144].

Dietary mediators like RA have been recently found to alter IECs homeostasis, where depletion of RAR $\alpha$ specifically in IECs (RAR $\alpha^{\text {villin }}$ mice) promoted IECs differentiation into a more secretory phenotype, with increased proportions of goblet cells and Paneth cells [145]. RA is proposed to control the immunomodulatory capacities of IECs, where it could paradoxically affect IEC-directed modulation of effector lymphocytes. For instance, IECs in the presence of RA imprint T-cell polarization by either suppressing or upregulating Th17 cells in different inflammatory milieus [146]. On the contrary, they can trigger Treg proliferation under steady state [147]. Therefore, further investigation around IEC-mediated immunoregulation in different contexts may be valuable for understanding their roles in regulating the balance of the intestinal barrier.

A strict regulation of intestinal permeability is required to maintain homeostasis. This can be achieved not only through functional IECs but by the active contribution of TJs. Different integral proteins, including the claudin family, interconnect with junctional proteins such as zonula occludens (ZO) to control the transfer of different molecules through the paracellular junctions. The disruption of these packed molecules is correlated with increased permeability and the induction of intestinal inflammation [148].

A wide range of factors shape the assembly and consequently the integrity and function of TJs. These range from dietary components and the food additives in industrial products [149] to the effect of gut microbiota itself [150]. For instance, a dietary lipid-derived aldehyde called Acrolein is found to downregulate and rearrange the expression of different TJs including Claudin-1, Occludin, and ZO-1 in both in vivo and in vitro settings, which in turn affects their capability of maintaining 
paracellular integrity [151]. Gut microbiota and/or their products, on the other hand, influence the epithelial TJs. For example, secreted products from Bifidobacterium infantis were found to promote the transmembrane electrical resistance (TER) in mice treated with B. infantis-conditioned medium, where it enhanced the expression of ZO-1 and Occludin while decreasing Claudin-2 expression [152]. Moreover, oral treatment with Lactobacillus spp. such as L. rhamnosus and L. acidophilus corrected the Shigella-dysenteriae-1-induced reduction of Claudin-1 and Occludin, which in turn increased intestinal barrier function in the treated rats [153]. These findings highlight the roles of gut microbiota as well as environmental factors in shaping the epithelial TJs and subsequently the intestinal permeability.

Indeed, the assembly or disassembly of TJs depends on an intricate network of modulators that control the phosphorylation and dephosphorylation of TJ proteins. This is mainly though activation of downstream signaling of kinases (including MAPKs, protein kinase C (PKCs) and Rho kinases (RhoK)) and phosphatases, respectively. For example, targeting of integral TJ proteins such as Occludin, a main regulator for TJs assembly, by these kinases or phosphatases can directly modify the structure of other TJs and consequently their dynamic barrier functions [154].

Previous reviews have proposed the mechanisms by which pro-/anti-inflammatory cytokines disrupt or promote TJs $[155,156]$. Modulation of kinase activity such as phosphorylation of extracellular signal-regulated kinases (ERKs) or classical MAPKs in response to ligation of different inflammatory cytokines to their epithelial targets directly contributes to epithelial barrier dysfunction and TJ disassembly. This is indicated by increased paracellular conductance and diminished TER following different cytokine treatments [157]. For example, upregulated expression of the channel-forming TJ protein Claudin-2 was noted with IL-22 treatment of Caco-2 cells. IL-22 ligation induced the activation of JAK/STAT signaling, which is proposed to upregulate Claudin-2 protein expression [158]. This finding may explain the increased level of IL-22 with intestinal inflammation [159] and highlight the roles of cytokine-induced regulation of intestinal barrier TJs.

Moreover, conserved microbial products such as lipopeptides and LPS were found to greatly affect the expression and continuity of TJs. For instance, sensing of TLR2 on IECs by bacterial lipopeptides has been shown to promote the phosphorylation of PKC that upregulates the expression of ZO-1 and consequently enhances the integrity of intestinal epithelium [160]. Similarly, TLR sensing upon recognition of LPS can modulate the expression of TJs and subsequently intestinal permeability [161]. Activation of TLR4/myeloid differentiation primary response 88 (MyD88) signaling through the LPS recognition by TLR4 upregulates the expression of myosin light chain kinase (MLCK) activities that can in turn modulate intestinal TJs leading to increased intestinal permeability [162].

Various studies have shown the direct correlation between intestinal inflammation and dysregulated junctions constituting a leaky gut $[163,164]$. For instance, upregulation of Claudin-2 is correlated with various IBD cases. Thus, targeting Claudin-2 through controlled intrinsic lysosomal-induced degradation or autophagy could provide a promising therapeutic intervention for such conditions [165]. Similarly, upregulation of Zonulin (a regulatory junctional protein) has been recently implicated in abnormal gut permeability and development of chronic intestinal inflammation in dextran sodium sulfate (DSS)-induced colitis [166]. Upregulated Zonulin expression was also correlated with bacterial dysbiosis and impaired permeability in clinical cases of ankylosing spondylitis [167]. These findings highlight the wide range of factors that imprint the intestinal barrier regulation linking barrier impairment to inflammation.

\subsection{Potential Mechanisms of How a Leaky Gut Leads to Autoimmunity}

The impaired intestinal barrier and the development of diseases in general have been extensively reviewed $[148,168,169]$. The paradigm that a leaky gut is a cause or a sequela to autoimmunity is a very active area of research. So far, findings suggest that a leaky gut is a cause of autoimmunity rather than a consequence [130]. In the following section, we will investigate the possible ways by which a leaky gut may contribute to autoimmunity (Figure 2). 
Intestinal microbial dysbiosis is proposed to induce epigenetic modifications that can upregulate TLR expression on APCs [170] and deviate the balance of T-cell subsets [171,172]. Similarly, microbial dysbiosis derives inappropriate post-translational modifications of luminal proteins, creating or exposing neo-antigenic determinants of self-proteins that in turn are recognized by immune cells as autoantigens, thus provoking autoimmunity [173]. Therefore, normalization of microbiota and/or their metabolites may provide a possible therapeutic avenue against autoimmune diseases through regulation of the host epigenome [174]. Moreover, leaky-gut-induced dysbiosis creates an inflammatory environment that can lead to the development of many autoimmune conditions. Intestinal barrier disruption will open the doors for intense immunologic defenses. Recognition of microbes or microbial products by lamina propria defenses will induce escalating proinflammatory cytokines, including IFN $\gamma, \mathrm{TNF} \alpha, \mathrm{IL}-1 \beta$, and IL-13. These cytokines could induce more damage to the intestinal mucosa as observed in chronic IBD [175]. In addition, increased Th1 and Th17 cytokines (IFN $\gamma$ and IL-17, respectively) as well as enhanced inflammatory activities of macrophages and DCs (e.g., increased IL-6 and TNF $\alpha$ levels) can damage multiple tissues, as observed in SLE. Mechanistically, this is most prominently through the induction of autoreactive $\mathrm{T}$ and $\mathrm{B}$ cells specific for autoantigens that are a result of the initial tissue destruction and through autoantibody production, with further deposition of immune complexes in tissues which subsequently escalates the damage signals [176]. Similarly, pro-inflammatory cytokines can damage the BBB by breaking down the myelin sheath, which directly contributes to the development of EAE, an experimental rodent model of MS [177]. Furthermore, the breakdown of epithelium associated with a leaky gut may increase microbial translocation to lymphoid tissues, provoking hyperinflammatory responses. For instance, microbial translocation to the pancreatic lymph nodes (PLNs) has been proposed to activate the nucleotide-binding oligomerization domain containing protein 2 (NOD2) signaling, initiating the myeloid proinflammatory cytokines IL-6 and $\mathrm{TNF} \alpha$, thus enhancing the Th1/Th17-induced damage of pancreatic $\beta$ cells. These events lead to pancreatic insulitis, which is associated with T1D, and can reestablish T1D in a diabetes-resistant mouse model [178].

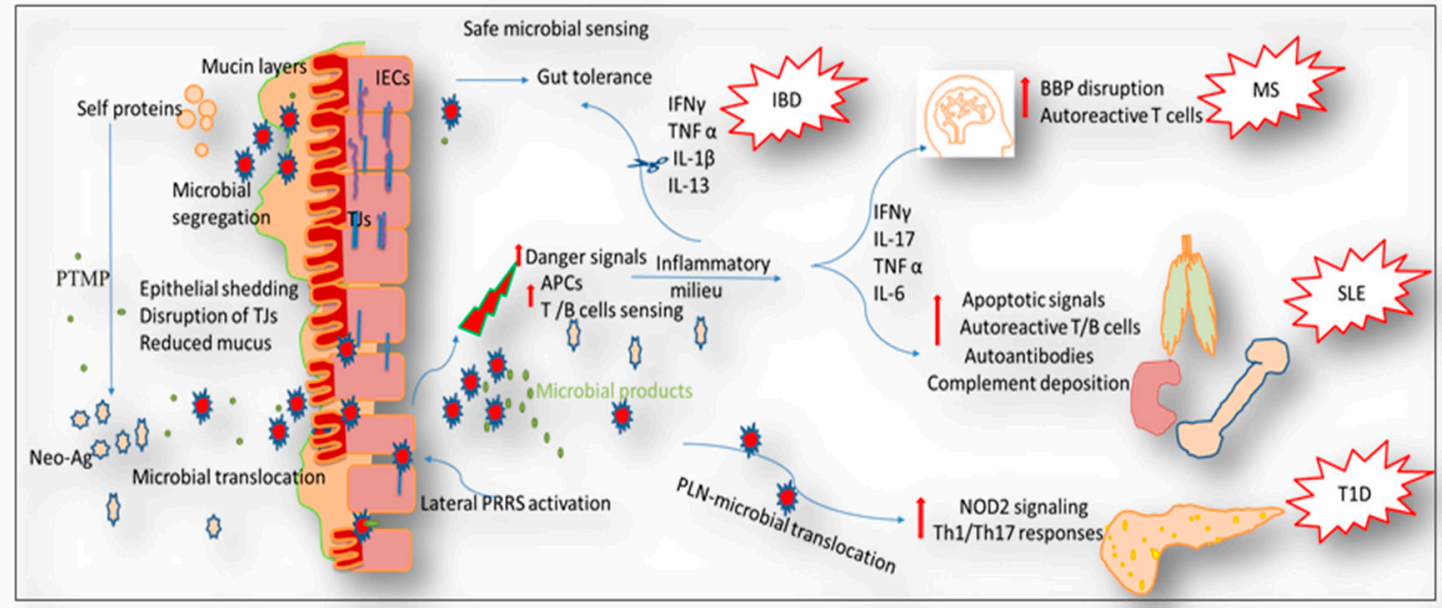

Figure 2. Possible mechanisms of how a leaky gut leads to autoimmunity. Breakdown of the integrity of the intestinal mucosa is associated with microbial dysbiosis. This could result in epigenetic changes of both self-protein and pattern recognition receptor (PRR) sensing. Increased danger signals following microbial dysbiosis provoke immunogenic cell responses, consequently upregulating different pro-inflammatory cytokines levels such as tumor necrosis factor (TNF) $\alpha$, IFN $\gamma$, IL-1, IL-17, IL-6, and IL-13. These inflammatory niches are associated with different pathologies including IBD, MS, SLE, and T1D. 


\subsection{Involvement of a Leaky Gut in Specific Autoimmune Diseases}

Gut dysbiosis is a nidus for the breakdown of immune tolerance at the mucosal interface, as we have discussed. A complex circuit of inflammation that could be manifested in any or all of the above mentioned autoimmune diseases indicates that a leaky gut may be a core for the initiation and progression of these pathologies. Here, we further discuss the involvement of a leaky gut in specific autoimmune conditions.

\subsubsection{T1D}

Even though the link between a leaky gut and T1D pathogenesis has been questioned [179], an expanding pool of literature has reviewed the link between microbiota dysbiosis and T1D pathogenesis $[180,181]$. Dysbiotic microbiota could represent a significant contributor to the development of T1D in animals with genetically predisposed backgrounds. For example, similarities in microbiota composition and gut dysfunction were observed among NOD mice housed in different facilities [126], indicating that a leaky gut may be a major player for T1D development. Importantly, impaired microbiota and their metabolites have been reported in human T1D patients, indicating the establishment of a leaky gut [125].

Diet-induced modulation of intestinal integrity and microbiota diversity that enhances the Firmicutes/Bacteroidetes ratio has been associated with impaired progression of T1D [182]. Additionally, feeding the NOD mice with an acetate/butyrate-producing specialized diet decreased gut permeability and boosted against T1D by diminishing the IL-21 inflammatory diabetogenic niche. Moreover, acetate-yielding diets markedly reduced the proliferation of autoreactive lymphocytes, and butyrate-producing diets upregulated Treg differentiation [183]. Interestingly, the reshaping of acetate-to-butyrate-producing gut microbiota ratios through fecal transfer from T1D-protected mice to germ-free (GF) NOD mice protected against T1D development in GF mice as well [184]. These findings further support the notion that the correction of leaky-gut-derived microbiota dysbiosis can be a therapeutic approach for T1D and other T-cell-mediated autoimmune conditions. Nevertheless, further studies on the gut microbiome-T1D axis are warranted.

\subsubsection{MS}

Although the exact etiology of this multifactorial neurological disorder is debated, a growing amount of evidence [185] links the onset and progression of MS to gut leakiness [127,128]. It has been proposed that dysbiotic microbiota may trigger MS neuroinflammation directly through their metabolites, which can cross the BBB and affect immune cells within the CNS [186]. However, even though microbiota dysbiosis has been established in many cases of MS, only the idea that MS is inflammatorily driven is widely accepted. The microbiota signature associated with the development of MS is actually speculative. Some argue that there is no typical signature that is equally manifested among different MS patients [187], while others speculate that the consistencies in certain microbiome signatures can be biomarkers for the diagnosis of MS [188].

Indeed, alteration of microbiota and their metabolites could be promising targets for treatment of MS, where the functional gut microbiota could contribute to the health of CNS in general, as previously reviewed [189]. Targeting of microbiota delayed EAE onset and hindered the disease progression in animal models [190]. Similarly, in pilot studies of clinical MS patients, correction of microbial dysbiosis was able to establish an anti-inflammatory niche through enhancing TGF $\beta /$ IL-10 levels, reducing IL-17 producing $\mathrm{CD}^{+} \mathrm{T}$ cells, and favoring Treg proliferation, which improved disease relapse [191]. Therefore, more studies on the microbiome-brain link may provide novel avenues for the treatment of MS.

\subsubsection{IBD}

A leaky gut or impaired intestinal permeability could be a signal for IBD initiation [192,193], as many observations have been shown to correlate defective intestinal epithelial barriers to IBD 
pathogenesis [194]. The interaction between barrier permeability, gut microbiota, and mucosal immune sensing and how this tri-circuit could lead to IBD have been extensively reviewed elsewhere $[195,196]$. Briefly, disruption of intestinal membrane TJs [164] and breaching of the intestinal mucosa can induce exaggerated responses to the gut microbiota which greatly contribute to IBD pathogenesis in genetically predisposed individuals [197].

Thus, combined therapies that involve immunomodulators [198,199], microbiota targeting [200,201] using commensals such as Escherichia coli [202], and probiotics such as Lactobacilli spp. [203], as well as normalization of barrier functions [195], might provide some relief for IBD patients. However, with emerging findings indicating that even with response to therapies, many patients still have ongoing progressive disease symptoms and increased intestinal permeability in spite of mucosal healing [204], other aspects of leaky-gut-induced IBD should be considered. For instance, targeting TJ proteins and improving IEC repair and proliferation may be therapeutically worthy, especially with promising findings that suggest a positive feedback loop between normalization of TJs [205] and epithelial modulation [206].

\subsubsection{SLE}

The relationship between dysbiotic microbiota, for example, the reduced Firmicutes/Bacteroidetes ratio, and SLE has been established [207]. Gut dysbiosis and increased intestinal permeability have been reported in both experimental animal models and human patients with lupus $[207,208]$. Altered microbiota composition was correlated to lupus progression in human patients and an NZB/W F1 lupus mouse model [209]. Recent data from our laboratory showed how microbiota manipulation and reversal of the leaky gut could improve disease prognosis. For instance, normalization of gut microbiota through antibiotics such as vancomycin improved epithelial integrity, as shown by decreased small intestinal and colonic permeability to FITC-conjugated dextran [210]. In addition, vancomycin enhanced the paracellular integrity by upregulating TJ proteins and reducing the translocation of bacteria or their products (e.g., LPS) to the mesenteric lymph nodes (MLN) and systemic circulation [210]. Similarly, correction of the leaky gut in MRL/lpr mice reversed the inflammatory niches and diminished lupus-related damage of extraintestinal organs such as the kidney in female mice [122]. These findings from our team provide further support for the implication of gut leakiness and microbiota dysbiosis in lupus progression and highlight the importance of microbiome-mediated therapy for disease control.

\section{Potential Roles of RA on the Leaky Gut and, Subsequently, Autoimmune Diseases}

Generally, the inverse relationship between serum retinol levels and gut permeability indicates a direct role of vitamin A metabolites in maintaining barrier functionality [211,212]. The data we have gathered and discussed throughout this review direct us to an interesting yet intricate question: Does RA directly improve the intestinal integrity and consequently hinder the autoimmunity, or does it exert indirect effects through regulating the gut microbiota? Notably, similar patterns of dysbiotic gut microbiota has been observed with VAD and clinical cases of autoimmunity. For instance, increased abundance of Bacteroides such as Bacteroides vulgatus, which has been associated with autoimmune conditions like T1D [213] and MS [214], has been observed in VAD [215]. Thus, here we will discuss several hypotheses that might suggest multiple interacting functions of RA.

\subsection{RA and TJ Proteins}

Impairment of TJs could represent a start for autoimmune pathologies. Therefore, exploring whether a dietary metabolite such as RA improves the expression and/or assembly of TJ proteins may provide novel therapeutic targets against autoimmune diseases.

RA has been reported to modulate the expression of cellular TJ proteins in various host tissues including the skin [216], kidney [217], and peritoneal tissues [218]. RA could affect intestinal permeability directly through the role of its RAR $\gamma-R X R \alpha$ heterodimers in formation of functional TJs of 
epithelial cells during visceral endoderm differentiation [219]. RA regulates the expression of TJ genes in epithelial cells. For example, RA supplementation to epithelial cells grown in transwell systems induced RAR $\alpha$-mediated transcriptional changes in the expression of different TJ proteins, including Claudin-1, Claudin-4, and ZO1, consequently augmenting the TER of the epithelial monolayer [220]. Furthermore, RA-RAR $\beta$ signaling has been found to enhance the expression of intestinal membrane proteins such as a sulfate anion transporter known as Down-Regulated in Adenoma (DRA) [221], which could improve TJ expression and counteract DSS-induced colitis [222]. Indirectly, the modulation of TJ gene expression through RA can be linked to the ability of RA to alter TLR-microbial sensing. For example, RA treatment to Caco-2 cells enhanced their TER through RAR $\beta$-mediated upregulation of TLR4, which in turn improved the expression of ZO-2, whereas the expression of TLR4 and ZO-2 was improved or diminished by the activation or silencing of RAR $\beta$, respectively [161]. TLR4 was a prerequisite for RAR $\beta$-induced ZO-2 expression, as RAR $\beta$ cannot directly bind to the ZO-2 gene promoter [161]. Moreover, RA can counteract oxidative-stress-induced disassembly of TJs. For example, in vitro treatment of RA or an RAR $\alpha$ agonist (Am580) could ameliorate the disruption of the epithelial monolayer TJs that had been induced by hydrogen peroxide $\left(\mathrm{H}_{2} \mathrm{O}_{2}\right)$ [220].

However, RA-directed regulation of TJ proteins is not well established for all tissues. For instance, RA was neither essential nor able to induce the expression of BBB TJs or adherent proteins in brain tissues [223]. This might direct us to our second hypothesis, which is that RA indirectly modulates the leaky gut through targeting the gut microbiota.

\subsection{Indirect Regulation through the Interaction of RA and Gut Microbiota}

The crosstalk between microbial communities and RA could imprint immune cell functions to not only maintain gut homeostasis but also regulate the functionality of peripheral lymphoid organs. For example, gut colonization with commensal fungi induced the migration of LP CD103 ${ }^{+}$ $\mathrm{RALDH}^{+}$DCs to the peripheral lymph nodes, where RA production by these migrating cells enhanced the homing capacity of the peripheral lymphocytes to the gut-associated lymphoid tissues and peripheral lymph nodes [224]. Moreover, induction of oral tolerance through microbial superantigens (e.g., staphylococcal enterotoxin A) has been linked to the ability of intestinal DCs to produce RA and the subsequent upregulation of Treg cells both in vivo and in vitro [225]. Furthermore, gut microbiota produce short-chain fatty acids that can also enhance RA production by IECs and contribute to the immunoregulatory functions of IECs through promoting tolerogenic DCs [147]. Those findings highlight a circuit of interaction between gut microbiota and RA signaling.

Recent findings highlight the link between the RA-microbiome axis and regulation of B-cell responses in the gut. Gut bacteria can produce acetate, and RA signaling is required for acetate-induced programming of intestinal B cells to become IgA-secreting cells [226]. Similarly, RA signaling is correlated with normalized gut microflora composition after the hapten 4-hydroxy-3-nitrophenyl acetyl-cholera toxin (NP-CT) oral immunization. In addition, RA signaling in B cells is essential for their class switching to IgA-secreting cells and consequently their gut immune function. Silencing of RAR $\alpha$ signaling was associated with reduced IgA-secreting cells and increased proportions of Lachnospiraceae and Lactobacillus/Streptococcus in fecal samples [37]. These results associate RA signaling with gut microbiota in the regulation of B-cell responses.

Furthermore, shaping microbiota composition and their metabolites via RA can derive tolerogenic Treg responses [227]. RA has been found to be essential for inducing the proliferation of Foxp $3^{+} \mathrm{T}$ cells and for promoting IL-10 upregulation in vitro [228]. Interestingly, RA signaling in human monocyte-derived (Mo)-DCs and myeloid-DCs is the prerequisite for B. infantis-induced immunomodulatory responses [229]. Production of RA by $\mathrm{CD} 103^{+} \mathrm{DCs}$ was directly linked to the enhanced abilities of $B$. infantis to control DDS-induced colitis by reducing both Th1 and Th17 populations. However, $B$. infantis maintains its effects on upregulation of Treg cells in the absence of RA signaling, suggesting an RA-independent mechanism as well [229]. Furthermore, an altered 
microbiota composition, such as reduced segmented filamentous bacteria (SFB), has been linked to abnormal regulation of Th17 cells through a DC-independent mechanisms in the absence of RA [230].

Indeed, the capability of RA signaling to shape the responses of mucosal immune cells depends on the specific microbiome microenvironment. For instance, in response to RAR $\alpha$ sensing, different commensal and probiotic microbiota may influence the programming of human Mo-DCs and T-cell polarization differently. Stimulating human Mo-DCs with E. coli or Morganella morganii provoked pronounced pro-inflammatory responses indicated by increased IFN $\gamma$-producing T cells and IL-17 responses [231]. However, conditioning of Mo-DCs with RA could indirectly shift T-cell programming. RA was able to reduce DCs' costimulatory signals, leading to mitigation of Th1 activation and minimal or undetectable Th17 responses against E. coli and M. morganii [231].

Results from our laboratory have demonstrated that altered Lachnospiraceae and Lactobacillus populations were associated with the development of autoimmune pathologies in SLE. Restoring such imbalance via RA-specifically, the upregulation of Lactobacillus colonization-can improve lupus symptoms [121]. In vitro findings provided more support to the interplay between RA and Lactobacillus spp. and the possible modulation of intestinal mucosal immunity. Treatment of mucosal DC cultures with the cell free supernatant of L. reuteri has been shown to augment RA-induced tolerogenic responses, such as increased IL-10 and Foxp3 expression, as well as reduced expression of several genes responsible for Ag uptake and presentation [232]. Interestingly, recent data showed the importance of RA-RAR signaling for maintaining gut microbiota homeostasis, where the absence of RAR $\alpha$ signaling was associated with overexpression of antimicrobial peptides such as Reg $3 \gamma$ from intestinal Paneth cells. This resulted in microbial dysbiosis represented by altered bacterial colonization with remarkable differences in the abundance of lactobacilli in the colon and SFB in both the ileum and colon of RAR $\alpha^{\text {villin }}$ mice [145].

Therefore, to determine whether RA directly modulates intestinal permeability and autoimmunity or indirectly through regulating the gut microbiota and specifically Lactobacillus spp., we could propose a study where the effects of RA are evaluated in the absence of Lactobacillus spp. It is likely that RA exerts protective effects against a leaky gut and, subsequently, autoimmune pathologies through both direct and indirect mechanisms.

\section{Concluding Remarks and Future Directions}

A significant amount of literature on the gut-autoimmune axis has reported on the involvement of a leaky gut in different autoimmune diseases, including T1D, MS, IBD, and SLE. With the side effects associated with immunosuppressive drugs that are currently used for controlling autoimmune pathologies and increased public awareness, the need for safer immunotherapeutics is imperative. Thus, natural metabolites such as RA may be a less risky approach for dealing with autoimmunity. However, as RA works with a microenvironment-specific mechanism that derives distinct and even controversial consequences, more studies are needed to unravel its immunomodulatory actions under different circumstances. Furthermore, although beyond the scope of our review, evidence exists linking RA toxicity to several acute and chronic diseases [233,234]. There is also evidence that RA can cause a temporary feedback inhibition to the production of endogenous RA itself $[235,236]$ Therefore, many of the short-term observations described in our review may be temporary consequences due to the feedback inhibitory effect of RA and that longer-term observations could actually reveal toxic effects that may, in fact, indicate a causal role for RA in these same autoimmune diseases. Thus, our hypothesis on the link between RA, leaky gut, and autoimmunity is relatively weak and requires more supporting evidence. Dissecting the complex roles of RA in different phases of autoimmune disease progression, understanding the cell-specific roles of RAR signaling, and studying how RA interplays differently with different microbiotas will improve our understanding of the immunoregulatory circuits led by RA. This may bring us closer to controlling different autoimmune pathologies. As RA has many immunomodulatory functions, uncovering more about the underlying cellular and molecular mechanisms behind the RA-microbiome axis is a very interesting area to explore. 
Author Contributions: Both authors listed have made substantial, direct, and intellectual contribution to the work.

Funding: Preparation of this manuscript was supported by the NIH/NIAMS under award numbers 1R01AR073240 and 1R15AR067418.

Conflicts of Interest: The authors declare no conflict of interest.

\section{References}

1. Manicassamy, S.; Pulendran, B. Retinoic acid-dependent regulation of immune responses by dendritic cells and macrophages. Semin. Immunol. 2009, 21, 22-27. [CrossRef] [PubMed]

2. Zhu, J.; Shi, X.G.; Chu, H.Y.; Tong, J.H.; Wang, Z.Y.; Naoe, T.; Waxman, S.; Chen, S.J.; Chen, Z. Effect of retinoic acid isomers on proliferation, differentiation and PML relocalization in the APL cell line NB4. Leukemia 1995, 9, 302-309. [PubMed]

3. Noy, N. Retinoid-binding proteins: Mediators of retinoid action. Biochem. J. 2000, 348 Pt 3, $481-495$. [CrossRef]

4. Johnson, A.; Chandraratna, R.A. Novel retinoids with receptor selectivity and functional selectivity. Br. J. Dermatol. 1999, 140 (Suppl. 54), 12-17. [CrossRef]

5. Levin, A.A.; Sturzenbecker, L.J.; Kazmer, S.; Bosakowski, T.; Huselton, C.; Allenby, G.; Speck, J.; Ratzeisen, C.; Rosenberger, M.; Lovey, A.; et al. 9-Cis retinoic acid stereoisomer binds and activates the nuclear receptor RXR $\alpha$. Nature 1992, 355, 359-361. [CrossRef] [PubMed]

6. Hall, J.A.; Grainger, J.R.; Spencer, S.P.; Belkaid, Y. The role of retinoic acid in tolerance and immunity. Immunity 2011, 35, 13-22. [CrossRef] [PubMed]

7. Erkelens, M.N.; Mebius, R.E. Retinoic Acid and Immune Homeostasis: A Balancing Act. Trends Immunol. 2017, 38, 168-180. [CrossRef] [PubMed]

8. Benbrook, D.M.; Chambon, P.; Rochette-Egly, C.; Asson-Batres, M.A. History of Retinoic Acid Receptors. In The Biochemistry of Retinoic Acid Receptors I: Structure, Activation, and Function at the Molecular Level; Springer: Dordrecht, The Netherlands, 2014; pp. 1-20.

9. Huang, P.; Chandra, V.; Rastinejad, F. Retinoic acid actions through mammalian nuclear receptors. Chem. Rev. 2014, 114, 233-254. [CrossRef] [PubMed]

10. DeLuca, H.F. Overview of general physiologic features and functions of vitamin D. Am. J. Clin. Nutr. 2004, 80, 1689S-1696S. [CrossRef] [PubMed]

11. Mendoza-Parra, M.-A.; Gronemeyer, H. Genome-wide studies of nuclear receptors in cell fate decisions. Semin. Cell Dev. Biol. 2013, 24, 706-715. [CrossRef] [PubMed]

12. Ordóñez-Morán, P.; Muñoz, A. Cell Cycle Nuclear receptors: Genomic and non-genomic effects converge. Cell Cycle 2009. [CrossRef] [PubMed]

13. Das, B.C.; Thapa, P.; Karki, R.; Das, S.; Mahapatra, S.; Liu, T.-C.; Torregroza, I.; Wallace, D.P.; Kambhampati, S.; Van Veldhuizen, P.; et al. Retinoic acid signaling pathways in development and diseases. Bioorg. Med. Chem. 2014, 22, 673-683. [CrossRef] [PubMed]

14. Schug, T.T.; Berry, D.C.; Shaw, N.S.; Travis, S.N.; Noy, N. Opposing Effects of Retinoic Acid on Cell Growth Result from Alternate Activation of Two Different Nuclear Receptors. Cell 2007, 129, 723-733. [CrossRef] [PubMed]

15. Bosch, A.; Bertran, S.P.; Lu, Y.; Garcia, A.; Jones, A.M.; Dawson, M.I.; Farias, E.F. Reversal by RAR $\alpha$ agonist Am580 of c-Myc-induced imbalance in RAR $\alpha / R A R \gamma$ expression during MMTV-Myc tumorigenesis. Breast Cancer Res. 2012, 14, R121. [CrossRef] [PubMed]

16. Duong, V.; Rochette-Egly, C. The molecular physiology of nuclear retinoic acid receptors. From health to disease. Biochim. Biophys. Acta Mol. Basis Dis. 2011, 1812, 1023-1031. [CrossRef] [PubMed]

17. Kastner, P.; Chan, S. Function of RAR $\alpha$ during the maturation of neutrophils. Oncogene 2001, 20, 7178-7185. [CrossRef] [PubMed]

18. Collins, S.J. The role of retinoids and retinoic acid receptors in normal hematopoiesis. Leukemia 2002, 16, 1896-1905. [CrossRef] [PubMed]

19. Miro Estruch, I.; Melchers, D.; Houtman, R.; de Haan, L.H.J.; Groten, J.P.; Louisse, J.; Rietjens, I.M.C.M. Characterization of the differential coregulator binding signatures of the Retinoic Acid Receptor subtypes upon (ant)agonist action. Biochim. Biophys. Acta Proteins Proteom. 2017, 1865, 1195-1206. [CrossRef] [PubMed] 
20. Rochette-Egly, C. Retinoic acid signaling and mouse embryonic stem cell differentiation: Cross talk between genomic and non-genomic effects of RA. Biochim. Biophys. Acta Mol. Cell Biol. Lipids 2015, 1851, 66-75. [CrossRef] [PubMed]

21. Al Tanoury, Z.; Piskunov, A.; Rochette-Egly, C. Vitamin A and retinoid signaling: Genomic and nongenomic effects. J. Lipid Res. 2013, 54, 1761-1775. [CrossRef] [PubMed]

22. Naderi, S.; Blomhoff, H.K. Retinoic acid prevents phosphorylation of pRB in normal human B lymphocytes: Regulation of cyclin E, cyclin A, and p21(Cip1). Blood 1999, 94, 1348-1358. [PubMed]

23. Ertesvag, A.; Aasheim, H.-C.; Naderi, S.; Blomhoff, H.K. Vitamin A potentiates CpG-mediated memory B-cell proliferation and differentiation: Involvement of early activation of p38MAPK. Blood 2007, 109, 3865-3872. [CrossRef] [PubMed]

24. Ertesvag, A.; Engedal, N.; Naderi, S.; Blomhoff, H.K. Retinoic acid stimulates the cell cycle machinery in normal T cells: Involvement of retinoic acid receptor-mediated IL-2 secretion. J. Immunol. 2002, 169, 5555-5563. [CrossRef] [PubMed]

25. Chang, H.-K.; Hou, W.-S. Retinoic acid modulates interferon- $\gamma$ production by hepatic natural killer T cells via phosphatase 2A and the extracellular signal-regulated kinase pathway. J. Interf. Cytokine Res. 2015, 35, 200-212. [CrossRef] [PubMed]

26. Xu, Q.; Jitkaew, S.; Choksi, S.; Kadigamuwa, C.; Qu, J.; Choe, M.; Jang, J.; Liu, C.; Liu, Z. The cytoplasmic nuclear receptor RAR $\gamma$ controls RIP1 initiated cell death when cIAP activity is inhibited. Nat. Commun. 2017, 8, 425. [CrossRef] [PubMed]

27. Larange, A.; Cheroutre, H. Retinoic Acid and Retinoic Acid Receptors as Pleiotropic Modulators of the Immune System. Annu. Rev. Immunol. 2016, 34, 369-394. [CrossRef] [PubMed]

28. Czarnewski, P.; Das, S.; Parigi, S.M.; Villablanca, E.J. Retinoic Acid and Its Role in Modulating Intestinal Innate Immunity. Nutrients 2017, 9. [CrossRef] [PubMed]

29. Wang, P.; Zheng, S.G. Regulatory T cells and B cells: Implication on autoimmune diseases. Int. J. Clin. Exp. Pathol. 2013, 6, 2668-2674. [PubMed]

30. Mariño, E.; Grey, S.T. B cells as effectors and regulators of autoimmunity. Autoimmunity 2012, 45, 377-387. [CrossRef] [PubMed]

31. Miyagaki, T.; Fujimoto, M.; Sato, S. Regulatory B cells in human inflammatory and autoimmune diseases: From mouse models to clinical research. Int. Immunol. 2015, 27, 495-504. [CrossRef] [PubMed]

32. Joseph, C.; Nota, C.; Fletcher, J.L.; Maluenda, A.C.; Green, A.C.; Purton, L.E. Retinoic Acid Receptor $\gamma$ Regulates B and T Lymphopoiesis via Nestin-Expressing Cells in the Bone Marrow and Thymic Microenvironments. J. Immunol. 2016, 196, 2132-2144. [CrossRef] [PubMed]

33. Ertesvåg, Å.; Naderi, S.; Blomhoff, H.K. Regulation of B cell proliferation and differentiation by retinoic acid. Semin. Immunol. 2009, 21, 36-41. [CrossRef] [PubMed]

34. Ross, A.C.; Chen, Q.; Ma, Y. Vitamin A and retinoic acid in the regulation of B-cell development and antibody production. Vitam. Horm. 2011, 86, 103-126. [CrossRef] [PubMed]

35. Di Caro, V.; Phillips, B.; Engman, C.; Harnaha, J.; Trucco, M. Retinoic acid-producing, ex-vivo-generated human tolerogenic dendritic cells induce the proliferation of immunosuppressive B lymphocytes. Clin. Exp. Immunol. 2013, 302-317. [CrossRef] [PubMed]

36. Marks, E.; Ortiz, C.; Pantazi, E.; Bailey, C.S.; Lord, G.M.; Waldschmidt, T.J.; Noelle, R.J.; Elgueta, R. Retinoic Acid Signaling in B Cells Is Required for the Generation of an Effective T-Independent Immune Response. Front. Immunol. 2016, 7, 643. [CrossRef] [PubMed]

37. Pantazi, E.; Marks, E.; Stolarczyk, E.; Lycke, N.; Noelle, R.J.; Elgueta, R. Cutting Edge: Retinoic Acid Signaling in B Cells Is Essential for Oral Immunization and Microflora Composition. J. Immunol. 2015, 195, 1368-1371. [CrossRef] [PubMed]

38. Seo, G.-Y.; Jang, Y.-S.; Kim, J.; Choe, J.; Han, H.-J.; Lee, J.-M.; Kang, S.-H.; Rhee, K.-J.; Park, S.-R.; Kim, W.-S.; et al. Retinoic acid acts as a selective human IgA switch factor. Hum. Immunol. 2014, 75, 923-929. [CrossRef] [PubMed]

39. Roy, B.; Brennecke, A.-M.; Agarwal, S.; Krey, M.; Düber, S.; Weiss, S. An Intrinsic Propensity of Murine Peritoneal B1b Cells to Switch to IgA in Presence of TGF- $\beta$ and Retinoic Acid. PLoS ONE 2013, 8, e82121. [CrossRef] [PubMed] 
40. Jang, Y.-S.; Seo, G.-Y.; Lee, J.-M.; Seo, H.-Y.; Han, H.-J.; Kim, S.-J.; Jin, B.-R.; Kim, H.-J.; Park, S.-R.; Rhee, K.-J.; et al. Lactoferrin causes $\operatorname{IgA}$ and $\operatorname{IgG} 2 \mathrm{~b}$ isotype switching through betaglycan binding and activation of canonical TGF- $\beta$ signaling. Mucosal Immunol. 2015, 8, 906-917. [CrossRef] [PubMed]

41. Kang, S.-H.; Jin, B.-R.; Kim, H.-J.; Seo, G.-Y.; Jang, Y.-S.; Kim, S.-J.; An, S.-J.; Park, S.-R.; Kim, W.-S.; Kim, P.-H. Lactoferrin Combined with Retinoic Acid Stimulates B1 Cells to Express IgA Isotype and Gut-homing Molecules. Immune Netw. 2015, 15, 37. [CrossRef] [PubMed]

42. Eriksen, A.B.; Indrevær, R.L.; Holm, K.L.; Landskron, J.; Blomhoff, H.K. TLR9-signaling is required for turning retinoic acid into a potent stimulator of RP105 (CD180)-mediated proliferation and IgG synthesis in human memory B cells. Cell. Immunol. 2012, 279, 87-95. [CrossRef] [PubMed]

43. Indrevaer, R.L.; Holm, K.L.; Aukrust, P.; Osnes, L.T.; Naderi, E.H.; Fevang, B.; Blomhoff, H.K. Retinoic Acid Improves Defective TLR9/RP105-Induced Immune Responses in Common Variable Immunodeficiency-Derived B Cells. J. Immunol. 2013, 191, 3624-3633. [CrossRef] [PubMed]

44. Indrevær, R.L.; Moskaug, J.Ø.; Paur, I.; Bøhn, S.K.; Jørgensen, S.F.; Blomhoff, R.; Aukrust, P.; Fevang, B.; Blomhoff, H.K. IRF4 Is a Critical Gene in Retinoic Acid-Mediated Plasma Cell Formation and Is Deregulated in Common Variable Immunodeficiency-Derived B Cells. J. Immunol. 2015, 195, 2601-2611. [CrossRef] [PubMed]

45. Lee, Y.C.; Li, J.; Deng, J.; Noelle, R.J. Lineage-specific ablation of retinoic acid synthesis impacts on the development of gut-tropic regulatory T cells and oral tolerance. J. Immunol. 2016, 196, 207-217.

46. Lu, L.; Lan, Q.; Li, Z.; Zhou, X.; Gu, J.; Li, Q.; Wang, J.; Chen, M.; Liu, Y.; Shen, Y.; et al. Critical role of all-trans retinoic acid in stabilizing human natural regulatory $\mathrm{T}$ cells under inflammatory conditions. Proc. Natl. Acad. Sci. USA 2014, 111, 3432-3440. [CrossRef] [PubMed]

47. Brown, C.C.; Esterhazy, D.; Sarde, A.; London, M.; Pullabhatla, V.; Osma-Garcia, I.; al-Bader, R.; Ortiz, C.; Elgueta, R.; Arno, M.; et al. Retinoic Acid Is Essential for Th1 Cell Lineage Stability and Prevents Transition to a Th17 Cell Program. Immunity 2015, 42, 499-511. [CrossRef] [PubMed]

48. Kang, S.G.; Wang, C.; Matsumoto, S.; Kim, C.H. High and low vitamin A therapies induce distinct FoxP3+ T-cell subsets and effectively control intestinal inflammation. Gastroenterology 2009, 137, 1391-1402. [CrossRef] [PubMed]

49. Moore, C.; Tejon, G.; Fuentes, C.; Hidalgo, Y.; Bono, M.R.; Maldonado, P.; Fernandez, R.; Wood, K.J.; Fierro, J.A.; Rosemblatt, M.; et al. Alloreactive regulatory T cells generated with retinoic acid prevent skin allograft rejection. Eur. J. Immunol. 2015, 45, 452-463. [CrossRef] [PubMed]

50. Mucida, D.; Park, Y.; Kim, G.; Turovskaya, O.; Scott, I.; Kronenberg, M.; Cheroutre, H. Reciprocal TH17 and Regulatory T Cell Differentiation Mediated by Retinoic Acid. Science 2007, 317, 256-260. [CrossRef] [PubMed]

51. Tejón, G.; Manríquez, V.; De Calisto, J.; Flores-Santibáñez, F.; Hidalgo, Y.; Crisóstomo, N.; Fernández, D.; Sauma, D.; Mora, J.R.; Bono, M.R.; et al. Vitamin A Impairs the Reprogramming of Tregs into IL-17-Producing Cells during Intestinal Inflammation. BioMed Res. Int. 2015, 2015. [CrossRef] [PubMed]

52. Basu, R.; Whitley, S.K.; Bhaumik, S.; Zindl, C.L.; Schoeb, T.R.; Benveniste, E.N.; Pear, W.S.; Hatton, R.D.; Weaver, C.T. IL-1 signaling modulates activation of STAT transcription factors to antagonize retinoic acid signaling and control the TH17 cell-iTreg cell balance. Nat. Immunol. 2015, 16, 286-295. [CrossRef] [PubMed]

53. Gajardo, T.; Pérez, F.; Terraza, C.; Campos-Mora, M.; Noelle, R.J.; Pino-Lagos, K. IL-33 enhances retinoic acid signaling on CD4+ T cells. Cytokine 2016, 85, 120-122. [CrossRef] [PubMed]

54. Hall, J.A.; Cannons, J.L.; Grainger, J.R.; Dos Santos, L.M.; Hand, T.W.; Naik, S.; Wohlfert, E.A.; Chou, D.B.; Oldenhove, G.; Robinson, M.; et al. Essential Role for Retinoic Acid in the Promotion of CD4+ T Cell Effector Responses via Retinoic Acid Receptor Alpha. Immunity 2011, 34, 435-447. [CrossRef] [PubMed]

55. Ma, Y.; Chen, Q.; Ross, A.C. Retinoic acid and polyriboinosinic:polyribocytidylic acid stimulate robust anti-tetanus antibody production while differentially regulating type 1 /type 2 cytokines and lymphocyte populations. J. Immunol. 2005, 174, 7961-7969. [CrossRef] [PubMed]

56. Bai, A.; Lu, N.; Zeng, H.; Li, Z.; Zhou, X.; Chen, J.; Liu, P.; Peng, Z.; Guo, Y. All-Trans Retinoic Acid Ameliorates Trinitrobenzene Sulfonic Acid-Induced Colitis by Shifting Th1 to Th2 Profile. J. Interf. Cytokine Res. 2010, 30, 399-406. [CrossRef] [PubMed]

57. Rivollier, A.M.C. Retinoic acid signalling is required for the efficient differentiation of CD4+ T cells into pathogenic effector cells during the development of intestinal inflammation. In Proceedings of the 17th International Congress of Mucosal Immunology, Berlin, Germany, 14-18 July 2015. 
58. Marie Christian, A.; Winston, W. Retinoic Acid Modulates the Early Expansion and Differentiation of CD4(+) T Cells During the Development of Intestinal Inflammation. In Proceedings of the 42 nd Annual Meeting of the Scandinavian Society for Immunology, Reykjavik, Iceland, 11-14 June 2014. [CrossRef]

59. Guo, Y.; Lee, Y.-C.; Brown, C.; Zhang, W.; Usherwood, E.; Noelle, R.J. Dissecting the Role of Retinoic Acid Receptor Isoforms in the CD8 Response to Infection. J. Immunol. 2014, 192, 3336. [CrossRef] [PubMed]

60. Holtmeier, W.; Kabelitz, D. gammadelta T cells link innate and adaptive immune responses. Chem. Immunol. Allergy 2005, 86, 151-183. [CrossRef] [PubMed]

61. Mielke, L.A.; Jones, S.A.; Raverdeau, M.; Higgs, R.; Stefanska, A.; Groom, J.R.; Misiak, A.; Dungan, L.S.; Sutton, C.E.; Streubel, G.; et al. Retinoic acid expression associates with enhanced IL-22 production by $\gamma \delta \mathrm{T}$ cells and innate lymphoid cells and attenuation of intestinal inflammation. J. Exp. Med. 2013, 210, 1117-1124. [CrossRef] [PubMed]

62. Sutton, C.E.; Lalor, S.J.; Sweeney, C.M.; Brereton, C.F.; Lavelle, E.C.; Mills, K.H.G. Interleukin-1 and IL-23 Induce Innate IL-17 Production from $\gamma \delta$ T Cells, Amplifying Th17 Responses and Autoimmunity. Immunity 2009, 31, 331-341. [CrossRef] [PubMed]

63. Paul, S.; Lal, G. Role of gamma-delta $(\gamma \delta)$ T cells in autoimmunity. J. Leukoc. Biol. 2015, 97, $259-271$. [CrossRef] [PubMed]

64. Malik, S.; Want, M.Y.; Awasthi, A. The Emerging Roles of Gamma-Delta T Cells in Tissue Inflammation in Experimental Autoimmune Encephalomyelitis. Front. Immunol. 2016, 7, 14. [CrossRef] [PubMed]

65. Papotto, P.H.; Reinhardt, A.; Prinz, I.; Silva-Santos, B. Innately versatile: $\gamma \delta 17 \mathrm{~T}$ cells in inflammatory and autoimmune diseases. J. Autoimmun. 2018, 87, 26-37. [CrossRef] [PubMed]

66. Raverdeau, M.; Breen, C.J.; Misiak, A.; Mills, K.H. Retinoic acid suppresses IL-17 production and pathogenic activity of $\gamma \delta$ T cells in CNS autoimmunity. Immunol. Cell Biol. 2016, 94, 763-773. [CrossRef] [PubMed]

67. Gratas, C.; Menot, M.L.; Dresch, C.; Chomienne, C. Retinoid acid supports granulocytic but not erythroid differentiation of myeloid progenitors in normal bone marrow cells. Leukemia 1993, 7, 1156-1162. [PubMed]

68. Tocci, A.; Parolini, I.; Gabbianelli, M.; Testa, U.; Luchetti, L.; Samoggia, P.; Masella, B.; Russo, G.; Valtieri, M.; Peschle, C. Dual action of retinoic acid on human embryonic/fetal hematopoiesis: Blockade of primitive progenitor proliferation and shift from multipotent/erythroid/monocytic to granulocytic differentiation program. Blood 1996, 88, 2878-2888. [PubMed]

69. Kastner, P.; Lawrence, H.J.; Waltzinger, C.; Ghyselinck, N.B.; Chambon, P.; Chan, S. Positive and negative regulation of granulopoiesis by endogenous RARalpha. Blood 2001, 97, 1314-1320. [CrossRef] [PubMed]

70. Purton, L.E.; Dworkin, S.; Olsen, G.H.; Walkley, C.R.; Fabb, S.A.; Collins, S.J.; Chambon, P. RAR $\gamma$ is critical for maintaining a balance between hematopoietic stem cell self-renewal and differentiation. J. Exp. Med. 2006, 203, 1283-1293. [CrossRef] [PubMed]

71. Brown, G.; Marchwicka, A.; Cunningham, A.; Toellner, K.-M.; Marcinkowska, E. Antagonizing Retinoic Acid Receptors Increases Myeloid Cell Production by Cultured Human Hematopoietic Stem Cells. Arch. Immunol. Ther. Exp. 2017, 65, 69-81. [CrossRef] [PubMed]

72. Vangundy, Z.C.; Guerau-de-arellano, M.; Baker, J.D.; Strange, H.R.; Olivo-marston, S.; Muth, D.C.; Papenfuss, T.L. Continuous retinoic acid induces the differentiation of mature regulatory monocytes but fails to induce regulatory dendritic cells. BMC Immunol. 2014, 15, 1-14. [CrossRef] [PubMed]

73. Gabrilovich, D.I.; Nagaraj, S. Myeloid-derived suppressor cells as regulators of the immune system. Nat. Rev. Immunol. 2009, 9, 162-174. [CrossRef] [PubMed]

74. Mirza, N.; Fishman, M.; Fricke, I.; Dunn, M.; Neuger, A.M.; Frost, T.J.; Lush, R.M.; Antonia, S.; Gabrilovich, D.I. All-trans-retinoic acid improves differentiation of myeloid cells and immune response in cancer patients. Cancer Res. 2006, 66, 9299-9307. [CrossRef] [PubMed]

75. Heine, A.; Flores, C.; Gevensleben, H.; Diehl, L.; Heikenwalder, M.; Ringelhan, M.; Janssen, K.-P.; Nitsche, U.; Garbi, N.; Brossart, P.; et al. Targeting myeloid derived suppressor cells with all-trans retinoic acid is highly time-dependent in therapeutic tumor vaccination. Oncoimmunology 2017, 6, e1338995. [CrossRef] [PubMed]

76. Liu, P.T.; Krutzik, S.R.; Kim, J.; Modlin, R.L. Cutting edge: All-trans retinoic acid down-regulates TLR2 expression and function. J. Immunol. 2005, 174, 2467-2470. [CrossRef] [PubMed]

77. Wojtal, K.A.; Wolfram, L.; Frey-Wagner, I.; Lang, S.; Scharl, M.; Vavricka, S.R.; Rogler, G. The effects of vitamin A on cells of innate immunity in vitro. Toxicol. Vitr. 2013, 27, 1525-1532. [CrossRef] [PubMed] 
78. Arts, R.J.W.; Blok, B.A.; van Crevel, R.; Joosten, L.A.B.; Aaby, P.; Benn, C.S.; Netea, M.G. Vitamin A induces inhibitory histone methylation modifications and down-regulates trained immunity in human monocytes. J. Leukoc. Biol. 2015, 98, 129-136. [CrossRef] [PubMed]

79. Sanders, T.J.; McCarthy, N.E.; Giles, E.M.; Davidson, K.L.M.; Haltalli, M.L.R.; Hazell, S.; Lindsay, J.O.; Stagg, A.J. Increased Production of Retinoic Acid by Intestinal Macrophages Contributes to Their Inflammatory Phenotype in Patients with Crohn's Disease. Gastroenterology 2014, 146, 1278-1288. [CrossRef] [PubMed]

80. Ouziel, R.; Trépo, E.; Cremer, A.; Moreno, C.; Degré, D.; Chaouni, M.; Vercruysse, V.; Quertinmont, E.; Devière, J.; Lemmers, A.; et al. Correction of all-trans retinoic acid deficiency in alcoholic cirrhosis lessens the excessive inflammatory monocyte response: A translational study. Liver Int. 2014, 34, 343-352. [CrossRef] [PubMed]

81. Bolon, B. Cellular and Molecular Mechanisms of Autoimmune Disease. Toxicol. Pathol. 2012, 40, $216-229$. [CrossRef] [PubMed]

82. Liao, X.; Ren, J.; Wei, C.-H.; Ross, A.C.; Cecere, T.E.; Jortner, B.S.; Ahmed, S.A.; Luo, X.M. Paradoxical Effects of All-Trans-Retinoic Acid on Lupus-Like Disease in the MRL/lpr Mouse Model. PLoS ONE 2015, 10, e0118176. [CrossRef] [PubMed]

83. Theus, M.H.; Sparks, J.B.; Liao, X.; Ren, J.; Luo, X.M. All-Trans-Retinoic Acid Augments the Histopathological Outcome of Neuroinflammation and Neurodegeneration in Lupus-Prone MRL/lpr Mice. J. Histochem. Cytochem. 2017, 65, 69-81. [CrossRef] [PubMed]

84. Hixson, E.J.; Burdeshaw, J.A.; Denine, E.P.; Harrison, S.D. Comparative subchronic toxicity of all-trans- and 13-cis- retinoic acid in Sprague-Dawley rats. Toxicol. Appl. Pharmacol. 1979, 47, 359-365. [CrossRef]

85. Hem, K.G.; Ossenkoppele, G.J. All-trans retinoic acid toxicity. Eur. J. Haematol. 1992, 49, 148-149. [CrossRef] [PubMed]

86. Kawasaki, E. Type 1 Diabetes and Autoimmunity. Clin. Pediatr. Endocrinol. 2014, 23, 99-105. [CrossRef] [PubMed]

87. Van, Y.-H.; Lee, W.-H.; Ortiz, S.; Lee, M.-H.; Qin, H.-J.; Liu, C.-P. All-trans retinoic acid inhibits type 1 diabetes by $\mathrm{T}$ regulatory (Treg)-dependent suppression of interferon-gamma-producing T-cells without affecting Th17 cells. Diabetes 2009, 58, 146-155. [CrossRef] [PubMed]

88. Brun, P.-J.; Grijalva, A.; Rausch, R.; Watson, E.; Yuen, J.J.; Das, B.C.; Shudo, K.; Kagechika, H.; Leibel, R.L.; Blaner, W.S. Retinoic acid receptor signaling is required to maintain glucose-stimulated insulin secretion and $\beta$-cell mass. FASEB J. 2015, 29, 671-683. [CrossRef] [PubMed]

89. Wang, Y.; Zhong, Y.J.; Wang, Y.Y.; Xing, J.; Wang, Z.M. All-trans retinoic acid prevents the development of type 1 diabetes by affecting the levels of interferon gamma and interleukin 4 in streptozotocin-induced murine diabetes model. Genet. Mol. Res. 2016, 15. [CrossRef] [PubMed]

90. Juang, J.-H.; Van, Y.-H.; Kuo, C.-H.; Lin, M.-Y.; Liu, Y.-H.; Chang, H.-Y. Prevention and Reversal of Diabetes by All-Trans Retinoid Acid and Exendin-4 in NOD Mice. Int. J. Endocrinol. 2014, 2014, 435481. [CrossRef] [PubMed]

91. Calabresi, P.A. Diagnosis and management of multiple sclerosis. Am. Fam. Physician 2004, 70, $1935-1944$. [PubMed]

92. Cantarel, B.L.; Waubant, E.; Chehoud, C.; Kuczynski, J.; DeSantis, T.Z.; Warrington, J.; Venkatesan, A.; Fraser, C.M.; Mowry, E.M. Gut microbiota in multiple sclerosis: Possible influence of immunomodulators. J. Investig. Med. 2015, 63, 729-734. [CrossRef] [PubMed]

93. Miyake, S.; Kim, S.; Suda, W.; Oshima, K.; Nakamura, M.; Matsuoka, T.; Chihara, N.; Tomita, A.; Sato, W.; Kim, S.-W.; et al. Dysbiosis in the Gut Microbiota of Patients with Multiple Sclerosis, with a Striking Depletion of Species Belonging to Clostridia XIVa and IV Clusters. PLoS ONE 2015, 10, e0137429. [CrossRef] [PubMed]

94. van den Hoogen, W.J.; Laman, J.D.; t Hart, B.A. Modulation of Multiple Sclerosis and Its Animal Model Experimental Autoimmune Encephalomyelitis by Food and Gut Microbiota. Front. Immunol. 2017, 8, 1081. [CrossRef] [PubMed]

95. Fragoso, Y.D.; Stoney, P.N.; McCaffery, P.J. The Evidence for a Beneficial Role of Vitamin A in Multiple Sclerosis. CNS Drugs 2014, 28, 291-299. [CrossRef] [PubMed]

96. Runia, T.F.; Hop, W.C.J.; de Rijke, Y.B.; Hintzen, R.Q. Vitamin A is not associated with exacerbations in multiple sclerosis. Mult. Scler. Relat. Disord. 2014, 3, 34-39. [CrossRef] [PubMed] 
97. Bitarafan, S.; Saboor-Yaraghi, A.; Sahraian, M.-A.; Nafissi, S.; Togha, M.; Beladi Moghadam, N.; Roostaei, T.; Siassi, F.; Eshraghian, M.-R.; Ghanaati, H.; et al. Impact of Vitamin A Supplementation on Disease Progression in Patients with Multiple Sclerosis. Arch. Iran. Med. 2015, 18, 435-440. [PubMed]

98. Bitarafan, S.; Saboor-Yaraghi, A.; Sahraian, M.-A.; Soltani, D.; Nafissi, S.; Togha, M.; Beladi Moghadam, N.; Roostaei, T.; Mohammadzadeh Honarvar, N.; Harirchian, M.-H. Effect of Vitamin A Supplementation on fatigue and depression in Multiple Sclerosis patients: A Double-Blind Placebo-Controlled Clinical Trial. Iran. J. Allergy Asthma Immunol. 2016, 15, 13-19. [PubMed]

99. Bitarafan, S.; Harirchian, M.H.; Sahraian, M.A.; Keramatipour, M.; Beladi Moghadam, N.; Togha, M.; Nafissi, S.; Siassi, F.; Eshraghian, M.R.; Mohammadzadeh Honarvar, N.; et al. Impact of Vitamin A Supplementation on RAR Gene Expression in Multiple Sclerosis Patients. J. Mol. Neurosci. 2013, 51, 478-484. [CrossRef] [PubMed]

100. Mizee, M.R.; Nijland, P.G.; van der Pol, S.M.A.; Drexhage, J.A.R.; van het Hof, B.; Mebius, R.; van der Valk, P.; van Horssen, J.; Reijerkerk, A.; de Vries, H.E. Astrocyte-derived retinoic acid: A novel regulator of blood-brain barrier function in multiple sclerosis. Acta Neuropathol. 2014, 128, 691-703. [CrossRef] [PubMed]

101. Eriksen, A.B.; Berge, T.; Gustavsen, M.W.; Leikfoss, I.S.; Bos, S.D.; Spurkland, A.; Harbo, H.F.; Blomhoff, H.K. Retinoic acid enhances the levels of IL-10 in TLR-stimulated B cells from patients with relapsing-remitting multiple sclerosis. J. Neuroimmunol. 2015, 278, 11-18. [CrossRef] [PubMed]

102. Saboor-Yaraghi, A.A.; Harirchian, M.H.; Mohammadzadeh Honarvar, N.; Bitarafan, S.; Abdolahi, M.; Siassi, F.; Salehi, E.; Sahraian, M.A.; Eshraghian, M.R.; Roostaei, T.; et al. The Effect of Vitamin A Supplementation on FoxP3 and TGF- $\beta$ Gene Expression in Avonex-Treated Multiple Sclerosis Patients. J. Mol. Neurosci. 2015, 56, 608-612. [CrossRef] [PubMed]

103. Kaplan, G.G.; Ng, S.C. Understanding and Preventing the Global Increase of Inflammatory Bowel Disease. Gastroenterology 2017, 152, 313-321. [CrossRef] [PubMed]

104. Dolan, K.T.; Chang, E.B. Diet, gut microbes, and the pathogenesis of inflammatory bowel diseases. Mol. Nutr. Food Res. 2017, 61, 1600129. [CrossRef] [PubMed]

105. Hanauer, S.B. Inflammatory bowel disease: Epidemiology, pathogenesis, and therapeutic opportunities. Inflamm. Bowel Dis. 2006, 12, S3-S9. [CrossRef] [PubMed]

106. Maloy, K.J.; Powrie, F. Intestinal homeostasis and its breakdown in inflammatory bowel disease. Nature 2011, 474, 298-306. [CrossRef] [PubMed]

107. Medeiros, S.R.; Pinheiro-Rosa, N.; Lemos, L.; Loli, F.G.; Pereira, A.G.; Santiago, A.F.; Pinter, E.C.; Alves, A.C.; Oliveira, J.S.; Cara, D.C.; et al. Vitamin A supplementation leads to increases in regulatory CD4+Foxp3+LAP+ T cells in mice. Nutrition 2015, 31, 1260-1265. [CrossRef] [PubMed]

108. Benson, M.J.; Pino-Lagos, K.; Rosemblatt, M.; Noelle, R.J. All-trans retinoic acid mediates enhanced T reg cell growth, differentiation, and gut homing in the face of high levels of co-stimulation. J. Exp. Med. 2007, 204, 1765-1774. [CrossRef] [PubMed]

109. Hong, K.; Zhang, Y.; Guo, Y.; Xie, J.; Wang, J.; He, X.; Lu, N.; Bai, A. All-trans retinoic acid attenuates experimental colitis through inhibition of NF-кB signaling. Immunol. Lett. 2014, 162, 34-40. [CrossRef] [PubMed]

110. Namachivayam, K.; MohanKumar, K.; Arbach, D.; Jagadeeswaran, R.; Jain, S.K.; Natarajan, V.; Mehta, D.; Jankov, R.P.; Maheshwari, A. All-Trans Retinoic Acid Induces TGF- $\beta 2$ in Intestinal Epithelial Cells via RhoAand p38 $\alpha$ MAPK-Mediated Activation of the Transcription Factor ATF2. PLoS ONE 2015, 10, e0134003. [CrossRef] [PubMed]

111. Rafa, H.; Saoula, H.; Belkhelfa, M.; Medjeber, O.; Soufli, I.; Toumi, R.; de Launoit, Y.; Moralès, O.; Nakmouche, M.; Delhem, N.; et al. IL-23/IL-17A Axis Correlates with the Nitric Oxide Pathway in Inflammatory Bowel Disease: Immunomodulatory Effect of Retinoic Acid. J. Interf. Cytokine Res. 2013, 33, 355-368. [CrossRef] [PubMed]

112. Auci, D.L.; Egilmez, N.K. Synergy of Transforming Growth Factor Beta 1 and All Trans Retinoic Acid in the Treatment of Inflammatory Bowel Disease: Role of Regulatory T cells. J. Gastroenterol. Pancreatol. Liver Disord. 2016, 3, 1-8. [CrossRef] [PubMed]

113. Bhattacharya, N.; Yuan, R.; Prestwood, T.R.; Penny, H.L.; DiMaio, M.A.; Reticker-Flynn, N.E.; Krois, C.R.; Kenkel, J.A.; Pham, T.D.; Carmi, Y.; et al. Normalizing Microbiota-Induced Retinoic Acid Deficiency Stimulates Protective CD8+ T Cell-Mediated Immunity in Colorectal Cancer. Immunity 2016, 45, 641-655. [CrossRef] [PubMed] 
114. Penny, H.L.; Prestwood, T.R.; Bhattacharya, N.; Sun, F.; Kenkel, J.A.; Davidson, M.G.; Shen, L.; Zuniga, L.A.; Seeley, E.S.; Pai, R.; et al. Restoring Retinoic Acid Attenuates Intestinal Inflammation and Tumorigenesis in APCMin/+ Mice. Cancer Immunol. Res. 2016, 4, 917-926. [CrossRef] [PubMed]

115. Rafa, H.; Benkhelifa, S.; AitYounes, S.; Saoula, H.; Belhadef, S.; Belkhelfa, M.; Boukercha, A.; Toumi, R.; Soufli, I.; Moralès, O.; et al. All-Trans Retinoic Acid Modulates TLR4/NF-kB Signaling Pathway Targeting TNF- $\alpha$ and Nitric Oxide Synthase 2 Expression in Colonic Mucosa during Ulcerative Colitis and Colitis Associated Cancer. Mediat. Inflamm. 2017, 2017, 1-16. [CrossRef] [PubMed]

116. Manson, J.J.; Rahman, A. Systemic lupus erythematosus. Orphanet J. Rare Dis. 2006, 1, 6. [CrossRef] [PubMed]

117. Tsokos, G.C. Systemic Lupus Erythematosus. N. Engl. J. Med. 2011, 365, 2110-2121. [CrossRef] [PubMed]

118. Kinoshita, K.; Funauchi, M. Therapeutic effect of retinoic acid in lupus nephritis. Nihon Rinsho Meneki Gakkai Kaishi 2012, 35, 1-7. [CrossRef] [PubMed]

119. Funauchi, M.; Nozaki, Y.; Kinoshita, K. THU0301 A Phase II Trial of Retinoids on Lupus Nephritis in A Single Center. Ann. Rheum. Dis. 2016, 75, 296. [CrossRef]

120. De Lema, G.P.; Lucio-Cazaña, F.J.; Molina, A.N.A.; Luckow, B.; Schmid, H.; de wIT, C.O.R.; Moreno-Manzano, V.; Banas, B.; Mampaso, F.; Schlöndorff, D. Retinoic acid treatment protects MRL/lpr lupus mice from the development of glomerular disease. Kidney Int. 2004, 66, 1018-1028. [CrossRef] [PubMed]

121. Zhang, H.; Liao, X.; Sparks, J.B.; Luo, X.M. Dynamics of gut microbiota in autoimmune lupus. Appl. Environ. Microbiol. 2014, 80, 7551-7560. [CrossRef] [PubMed]

122. Mu, Q.; Zhang, H.; Liao, X.; Lin, K.; Liu, H.; Edwards, M.R.; Ahmed, S.A.; Yuan, R.; Li, L.; Cecere, T.E.; et al. Control of lupus nephritis by changes of gut microbiota. Microbiome 2017, 5, 73. [CrossRef] [PubMed]

123. Handono, K.; Firdausi, S.N.; Pratama, M.Z.; Endharti, A.T.; Kalim, H. Vitamin A improve Th17 and Treg regulation in systemic lupus erythematosus. Clin. Rheumatol. 2016, 35, 631-638. [CrossRef] [PubMed]

124. Wei, S.; Yoshida, N.; Finn, G.; Kozono, S.; Nechama, M.; Kyttaris, V.C.; Zhen Zhou, X.; Tsokos, G.C.; Ping Lu, K. Pin1-Targeted Therapy for Systemic Lupus Erythematosus. Arthritis Rheumatol. 2016, 68, 2503-2513. [CrossRef] [PubMed]

125. De Groot, P.F.; Belzer, C.; Aydin, Ö.; Levin, E.; Levels, J.H.; Aalvink, S.; Boot, F.; Holleman, F.; van Raalte, D.H.; Scheithauer, T.P.; et al. Distinct fecal and oral microbiota composition in human type 1 diabetes, an observational study. PLoS ONE 2017, 12, e0188475. [CrossRef] [PubMed]

126. Mullaney, J.A.; Stephens, J.E.; Costello, M.-E.; Fong, C.; Geeling, B.E.; Gavin, P.G.; Wright, C.M.; Spector, T.D.; Brown, M.A.; Hamilton-Williams, E.E. Type 1 diabetes susceptibility alleles are associated with distinct alterations in the gut microbiota. Microbiome 2018, 6, 35. [CrossRef] [PubMed]

127. Wekerle, H.; Hohlfeld, R. Gut Microbiota in Multiple Sclerosis. In Translational Neuroimmunology in Multiple Sclerosis; Elsevier: New York, NY, USA, 2016; pp. 113-125. ISBN 9780128019146.

128. Buscarinu, M.C.; Romano, S.; Mechelli, R.; Pizzolato Umeton, R.; Ferraldeschi, M.; Fornasiero, A.; Reniè, R.; Cerasoli, B.; Morena, E.; Romano, C.; et al. Intestinal Permeability in Relapsing-Remitting Multiple Sclerosis. Neurotherapeutics 2018, 15, 68-74. [CrossRef] [PubMed]

129. Fasano, A. Leaky Gut and Autoimmune Diseases. Clin. Rev. Allergy Immunol. 2012, 42, 71-78. [CrossRef] [PubMed]

130. Mu, Q.; Kirby, J.; Reilly, C.M.; Luo, X.M. Leaky Gut As a Danger Signal for Autoimmune Diseases. Front. Immunol. 2017, 8, 598. [CrossRef] [PubMed]

131. Arrieta, M.C.; Bistritz, L.; Meddings, J.B. Alterations in intestinal permeability. Gut 2006, 55, $1512-1520$. [CrossRef] [PubMed]

132. Scaldaferri, F.; Pizzoferrato, M.; Gerardi, V.; Lopetuso, L.; Gasbarrini, A. The gut barrier: New acquisitions and therapeutic approaches. J. Clin. Gastroenterol. 2012, 46, S12-S17. [CrossRef] [PubMed]

133. Lyu, Y.; Wu, L.; Wang, F.; Shen, X.; Lin, D. Carotenoid supplementation and retinoic acid in immunoglobulin A regulation of the gut microbiota dysbiosis. Exp. Biol. Med. 2018, 243, 613-620. [CrossRef] [PubMed]

134. Ramanan, D.; Cadwell, K. Intrinsic Defense Mechanisms of the Intestinal Epithelium. Cell Host Microbe 2016, 19, 434-441. [CrossRef] [PubMed]

135. Kim, Y.S.; Ho, S.B. Intestinal Goblet Cells and Mucins in Health and Disease: Recent Insights and Progress. Curr. Gastroenterol. Rep. 2010, 12, 319-330. [CrossRef] [PubMed]

136. Boltin, D.; Perets, T.T.; Vilkin, A.; Niv, Y. Mucin Function in Inflammatory Bowel Disease. J. Clin. Gastroenterol. 2013, 47, 106-111. [CrossRef] [PubMed] 
137. Volynets, V.; Rings, A.; Ongyi, G.; Ardos, B.; Ostaff, M.J.; Wehkamp, J.; Bischoff, S.C. Intestinal barrier analysis by assessment of mucins, tight junctions, and a-defensins in healthy C57BL/6J and BALB/cJ mice. Tissue Barriers 2016, 4. [CrossRef] [PubMed]

138. Robinson, K.; Deng, Z.; Hou, Y.; Zhang, G. Regulation of the Intestinal Barrier Function by Host Defense Peptides. Front. Vet. Sci. 2015, 2, 57. [CrossRef] [PubMed]

139. Peterson, L.W.; Artis, D. Intestinal epithelial cells: Regulators of barrier function and immune homeostasis. Nat. Rev. Immunol. 2014, 14, 141-153. [CrossRef] [PubMed]

140. Iliev, I.D.; Mileti, E.; Matteoli, G.; Chieppa, M.; Rescigno, M. Intestinal epithelial cells promote colitis-protective regulatory T-cell differentiation through dendritic cell conditioning. Mucosal Immunol. 2009, 2, 340-350. [CrossRef] [PubMed]

141. McDonald, K.G.; Leach, M.R.; Brooke, K.W.M.; Wang, C.; Wheeler, L.W.; Hanly, E.K.; Rowley, C.W.; Levin, M.S.; Wagner, M.; Li, E.; et al. Epithelial Expression of the Cytosolic Retinoid Chaperone Cellular Retinol Binding Protein II Is Essential for in Vivo Imprinting of Local Gut Dendritic Cells by Lumenal Retinoids. Am. J. Pathol. 2012, 180, 984-997. [CrossRef] [PubMed]

142. Maldonado-Contreras, A.L.; McCormick, B.A. Intestinal epithelial cells and their role in innate mucosal immunity. Cell Tissue Res. 2011, 343, 5-12. [CrossRef] [PubMed]

143. Rescigno, M. The intestinal epithelial barrier in the control of homeostasis and immunity. Trends Immunol. 2011, 32, 256-264. [CrossRef] [PubMed]

144. Williams, J.M.; Duckworth, C.A.; Burkitt, M.D.; Watson, A.J.M.; Campbell, B.J.; Pritchard, D.M. Epithelial cell shedding and barrier function: A matter of life and death at the small intestinal villus tip. Vet. Pathol. 2015, 52, 445-455. [CrossRef] [PubMed]

145. Jijon, H.B.; Suarez-Lopez, L.; Diaz, O.E.; Das, S.; De Calisto, J.; Yaffe, M.B.; Pittet, M.J.; Mora, J.R.; Belkaid, Y.; Xavier, R.J.; et al. Intestinal epithelial cell-specific RAR $\alpha$ depletion results in aberrant epithelial cell homeostasis and underdeveloped immune system. Mucosal Immunol. 2018, 11, 703-715. [CrossRef] [PubMed]

146. Chatterjee, A.; Gogolak, P.; Blottière, H.M.; Rajnavölgyi, É. The impact of ATRA on shaping human myeloid cell responses to epithelial cell-derived stimuli and on T-lymphocyte polarization. Mediat. Inflamm. 2015, 2015, 579830. [CrossRef] [PubMed]

147. Goverse, G.; Molenaar, R.; Macia, L.; Tan, J.; Erkelens, M.N.; Konijn, T.; Knippenberg, M.; Cook, E.C.L.; Hanekamp, D.; Veldhoen, M.; et al. Diet-Derived Short Chain Fatty Acids Stimulate Intestinal Epithelial Cells to Induce Mucosal Tolerogenic Dendritic Cells. J. Immunol. 2017, 198, 2172-2181. [CrossRef] [PubMed]

148. Camilleri, M.; Madsen, K.; Spiller, R.; Greenwood-Van Meerveld, B.; Van Meerveld, B.G.; Verne, G.N. Intestinal barrier function in health and gastrointestinal disease. Neurogastroenterol. Motil. 2012, 24, 503-512. [CrossRef] [PubMed]

149. Lerner, A.; Matthias, T. Changes in intestinal tight junction permeability associated with industrial food additives explain the rising incidence of autoimmune disease. Autoimmun. Rev. 2015, 14, 479-489. [CrossRef] [PubMed]

150. Castoldi, A.; Favero de Aguiar, C.; Moraes-Vieira, P.M.; Olsen Saraiva Câmara, N. They Must Hold Tight: Junction Proteins, Microbiota And Immunity In Intestinal Mucosa. Curr. Protein Pept. Sci. 2015, 16, 655-671. [CrossRef] [PubMed]

151. Chen, W.-Y.; Wang, M.; Zhang, J.; Barve, S.S.; McClain, C.J.; Joshi-Barve, S. Acrolein Disrupts Tight Junction Proteins and Causes Endoplasmic Reticulum Stress-Mediated Epithelial Cell Death Leading to Intestinal Barrier Dysfunction and Permeability. Am. J. Pathol. 2017, 187, 2686-2697. [CrossRef] [PubMed]

152. Ewaschuk, J.B.; Diaz, H.; Meddings, L.; Diederichs, B.; Dmytrash, A.; Backer, J.; Looijer-van Langen, M.; Madsen, K.L. Secreted bioactive factors from Bifidobacterium infantis enhance epithelial cell barrier function. Am. J. Physiol. Liver Physiol. 2008, 295, G1025-G1034. [CrossRef] [PubMed]

153. Moorthy, G.; Murali, M.R.; Devaraj, S.N. Lactobacilli facilitate maintenance of intestinal membrane integrity during Shigella dysenteriae 1 infection in rats. Nutrition 2009, 25, 350-358. [CrossRef] [PubMed]

154. Dörfel, M.J.; Huber, O. Modulation of Tight Junction Structure and Function by Kinases and Phosphatases Targeting Occludin. J. BioMed Biotechnol. 2012, 2012, 1-14. [CrossRef] [PubMed]

155. Al-Sadi, R.; Boivin, M.; Ma, T. Mechanism of cytokine modulation of epithelial tight junction barrier. Front. Biosci. 2009, 14, 2765-2778. [CrossRef]

156. Capaldo, C.T.; Nusrat, A. Cytokine regulation of tight junctions. Biochim. Biophys. Acta Biomembr. 2009, 1788, 864-871. [CrossRef] [PubMed] 
157. Petecchia, L.; Sabatini, F.; Usai, C.; Caci, E.; Varesio, L.; Rossi, G.A. Cytokines induce tight junction disassembly in airway cells via an EGFR-dependent MAPK/ERK1/2-pathway. Lab. Investig. 2012, 92, 1140-1148. [CrossRef] [PubMed]

158. Wang, Y.; Mumm, J.B.; Herbst, R.; Kolbeck, R.; Wang, Y. IL-22 Increases Permeability of Intestinal Epithelial Tight Junctions by Enhancing Claudin-2 Expression. J. Immunol. 2017, 199, 3316-3325. [CrossRef] [PubMed]

159. Dudakov, J.A.; Hanash, A.M.; van den Brink, M.R.M. Interleukin-22: Immunobiology and Pathology. Annu. Rev. Immunol. 2015, 33, 747-785. [CrossRef] [PubMed]

160. Cario, E.; Gerken, G.; Podolsky, D.K. Toll-like receptor 2 enhances ZO-1-associated intestinal epithelial barrier integrity via protein kinase C. Gastroenterology 2004, 127, 224-238. [CrossRef] [PubMed]

161. Li, Y.; Gao, Y.; Cui, T.; Yang, T.; Liu, L.; Li, T.; Chen, J. Retinoic Acid Facilitates Toll-Like Receptor 4 Expression to Improve Intestinal Barrier Function through Retinoic Acid Receptor Beta. Cell. Physiol. Biochem. 2017, 42, 1390-1406. [CrossRef] [PubMed]

162. Nighot, M.; Al-Sadi, R.; Guo, S.; Rawat, M.; Nighot, P.; Watterson, M.D.; Ma, T.Y. Lipopolysaccharide-Induced Increase in Intestinal Epithelial Tight Permeability Is Mediated by Toll-Like Receptor 4/Myeloid Differentiation Primary Response 88 (MyD88) Activation of Myosin Light Chain Kinase Expression. Am. J. Pathol. 2017, 187, 2698-2710. [CrossRef] [PubMed]

163. Fasano, A. Zonulin and Its Regulation of Intestinal Barrier Function: The Biological Door to Inflammation, Autoimmunity, and Cancer. Physiol. Rev. 2011, 91, 151-175. [CrossRef] [PubMed]

164. Lee, S.H. Intestinal Permeability Regulation by Tight Junction: Implication on Inflammatory Bowel Diseases. Intestig. Res. 2015, 13, 11. [CrossRef] [PubMed]

165. Hu, C.-A.A.; Hou, Y.; Yi, D.; Qiu, Y.; Wu, G.; Kong, X.; Yin, Y. Autophagy and tight junction proteins in the intestine and intestinal diseases. Anim. Nutr. 2015, 1, 123-127. [CrossRef] [PubMed]

166. Sturgeon, C.; Lan, J.; Fasano, A. Zonulin transgenic mice show altered gut permeability and increased morbidity/mortality in the DSS colitis model. Ann. N. Y. Acad. Sci. 2017, 1397, 130-142. [CrossRef] [PubMed]

167. Ciccia, F.; Guggino, G.; Rizzo, A.; Alessandro, R.; Luchetti, M.M.; Milling, S.; Saieva, L.; Cypers, H.; Stampone, T.; Di Benedetto, P.; et al. Dysbiosis and zonulin upregulation alter gut epithelial and vascular barriers in patients with ankylosing spondylitis. Ann. Rheum. Dis. 2017, 76, 1123-1132. [CrossRef] [PubMed]

168. Bischoff, S.C.; Barbara, G.; Buurman, W.; Ockhuizen, T.; Schulzke, J.-D.; Serino, M.; Tilg, H.; Watson, A.; Wells, J.M. Intestinal permeability-a new target for disease prevention and therapy. BMC Gastroenterol. 2014, 14, 189. [CrossRef] [PubMed]

169. König, J.; Wells, J.; Cani, P.D.; García-Ródenas, C.L.; MacDonald, T.; Mercenier, A.; Whyte, J.; Troost, F.; Brummer, R.-J. Human Intestinal Barrier Function in Health and Disease. Clin. Transl. Gastroenterol. 2016, 7, e196. [CrossRef] [PubMed]

170. Ignacio, A.; Morales, C.I.; Camara, N.O.S.; Almeida, R.R. Innate sensing of the gut microbiota: Modulation of inflammatory and autoimmune diseases. Front. Immunol. 2016. [CrossRef] [PubMed]

171. Abdollahi-Roodsaz, S.; Joosten, L.A.B.; Koenders, M.I.; Devesa, I.; Roelofs, M.F.; Radstake, T.R.D.J.; Heuvelmans-Jacobs, M.; Akira, S.; Nicklin, M.J.H.; Ribeiro-Dias, F.; et al. Stimulation of TLR2 and TLR4 differentially skews the balance of $\mathrm{T}$ cells in a mouse model of arthritis. J. Clin. Investig. 2008. [CrossRef] [PubMed]

172. Maeda, Y.; Kurakawa, T.; Umemoto, E.; Motooka, D.; Ito, Y.; Gotoh, K.; Hirota, K.; Matsushita, M.; Furuta, Y.; Narazaki, M.; et al. Dysbiosis Contributes to Arthritis Development via Activation of Autoreactive T Cells in the Intestine. Arthritis Rheumatol. 2016. [CrossRef] [PubMed]

173. Opdenakker, G.; Proost, P.; Van Damme, J. Microbiomic and Posttranslational Modifications as Preludes to Autoimmune Diseases. Trends Mol. Med. 2016, 22, 746-757. [CrossRef] [PubMed]

174. Lee, E.-S.; Song, E.-J.; Nam, Y.-D. Dysbiosis of Gut Microbiome and Its Impact on Epigenetic Regulation. J. Clin. Epigenet. 2017. [CrossRef]

175. Kiesslich, R.; Duckworth, C.A.; Moussata, D.; Gloeckner, A.; Lim, L.G.; Goetz, M.; Pritchard, D.M.; Galle, P.R.; Neurath, M.F.; Watson, A.J.M. Local barrier dysfunction identified by confocal laser endomicroscopy predicts relapse in inflammatory bowel disease. Gut 2012, 61, 1146-1153. [CrossRef] [PubMed]

176. Ohl, K.; Tenbrock, K. Inflammatory cytokines in systemic lupus erythematosus. J. BioMed Biotechnol. 2011, 2011, 432595. [CrossRef] [PubMed] 
177. Nouri, M.; Bredberg, A.; Weström, B.; Lavasani, S. Intestinal Barrier Dysfunction Develops at the Onset of Experimental Autoimmune Encephalomyelitis, and Can Be Induced by Adoptive Transfer of Auto-Reactive T Cells. PLoS ONE 2014, 9, e106335. [CrossRef] [PubMed]

178. Costa, F.R.C.; Françozo, M.C.S.; de Oliveira, G.G.; Ignacio, A.; Castoldi, A.; Zamboni, D.S.; Ramos, S.G.; Câmara, N.O.; de Zoete, M.R.; Palm, N.W.; et al. Gut microbiota translocation to the pancreatic lymph nodes triggers NOD2 activation and contributes to T1D onset. J. Exp. Med. 2016, 213, 1223-1239. [CrossRef] [PubMed]

179. Li, X.; Atkinson, M.A. The role for gut permeability in the pathogenesis of type 1 diabetes-A solid or leaky concept? Pediatr. Diabetes 2015, 16, 485-492. [CrossRef] [PubMed]

180. Hu, C.; Wong, F.S.; Wen, L. Type 1 diabetes and gut microbiota: Friend or foe? Pharmacol. Res. 2015, 98, 9-15. [CrossRef] [PubMed]

181. Bibbò, S.; Dore, M.P.; Pes, G.M.; Delitala, G.; Delitala, A.P. Is there a role for gut microbiota in type 1 diabetes pathogenesis? Ann. Med. 2017, 49, 11-22. [CrossRef] [PubMed]

182. Chen, K.; Chen, H.; Faas, M.M.; de Haan, B.J.; Li, J.; Xiao, P.; Zhang, H.; Diana, J.; de Vos, P.; Sun, J. Specific inulin-type fructan fibers protect against autoimmune diabetes by modulating gut immunity, barrier function, and microbiota homeostasis. Mol. Nutr. Food Res. 2017, 61, 1601006. [CrossRef] [PubMed]

183. Mariño, E.; Richards, J.L.; McLeod, K.H.; Stanley, D.; Yap, Y.A.; Knight, J.; McKenzie, C.; Kranich, J.; Oliveira, A.C.; Rossello, F.J.; et al. Gut microbial metabolites limit the frequency of autoimmune T cells and protect against type 1 diabetes. Nat. Immunol. 2017, 18, 552-562. [CrossRef] [PubMed]

184. McLeod, K.; Mason, L.; Mariño, E. Transplantation of Fecal Microbiota Shaped by Diet. BIO-PROTOCOL 2018, 7. [CrossRef]

185. Fleck, A.-K.; Schuppan, D.; Wiendl, H.; Klotz, L. Gut-CNS-Axis as Possibility to Modulate Inflammatory Disease Activity-Implications for Multiple Sclerosis. Int. J. Mol. Sci. 2017, 18, 1526. [CrossRef] [PubMed]

186. Dopkins, N.; Nagarkatti, P.S.; Nagarkatti, M. The role of gut microbiome and associated metabolome in the regulation of neuroinflammation in multiple sclerosis and its implications in attenuating chronic inflammation in other inflammatory and autoimmune disorders. Immunology 2018. [CrossRef] [PubMed]

187. Freedman, S.N.; Shahi, S.K.; Mangalam, A.K. The "Gut Feeling": Breaking Down the Role of Gut Microbiome in Multiple Sclerosis. Neurotherapeutics 2017, 1-17. [CrossRef] [PubMed]

188. Calvo-Barreiro, L.; Eixarch, H.; Montalban, X.; Espejo, C. Combined therapies to treat complex diseases: The role of the gut microbiota in multiple sclerosis. Autoimmun. Rev. 2018, 17, 165-174. [CrossRef] [PubMed]

189. Galland, L. The gut microbiome and the brain. J. Med. Food 2014, 17, 1261-1272. [CrossRef] [PubMed]

190. Libbey, J.E.; Sanchez, J.M.; Doty, D.J.; Sim, J.T.; Cusick, M.F.; Cox, J.E.; Fischer, K.F.; Round, J.L.; Fujinami, R.S. Variations in diet cause alterations in microbiota and metabolites that follow changes in disease severity in a multiple sclerosis model. Benef. Microbes 2018, 1-20. [CrossRef] [PubMed]

191. Saresella, M.; Mendozzi, L.; Rossi, V.; Mazzali, F.; Piancone, F.; LaRosa, F.; Marventano, I.; Caputo, D.; Felis, G.E.; Clerici, M. Immunological and Clinical Effect of Diet Modulation of the Gut Microbiome in Multiple Sclerosis Patients: A Pilot Study. Front. Immunol. 2017, 8, 1391. [CrossRef] [PubMed]

192. Peeters, M.; Geypens, B.; Claus, D.; Nevens, H.; Ghoos, Y.; Verbeke, G.; Baert, F.; Vermeire, S.; Vlietinck, R.; Rutgeerts, P. Clustering of increased small intestinal permeability in families with Crohn's disease. Gastroenterology 1997, 113, 802-807. [CrossRef]

193. Kevans, D.; Turpin, W.; Madsen, K.; Meddings, J.; Shestopaloff, K.; Xu, W.; Moreno-Hagelsieb, G.; Griffiths, A.; Silverberg, M.S.; Paterson, A.; et al. GEM Project Determinants of Intestinal Permeability in Healthy First-Degree Relatives of Individuals with Crohn's Disease. Inflamm. Bowel Dis. 2015, 21, 879-887. [CrossRef] [PubMed]

194. Salim, S.Y.; Söderholm, J.D. Importance of disrupted intestinal barrier in inflammatory bowel diseases. Inflamm. Bowel Dis. 2011, 17, 362-381. [CrossRef] [PubMed]

195. Vindigni, S.M.; Zisman, T.L.; Suskind, D.L.; Damman, C.J. The intestinal microbiome, barrier function, and immune system in inflammatory bowel disease: A tripartite pathophysiological circuit with implications for new therapeutic directions. Therap. Adv. Gastroenterol. 2016, 9, 606-625. [CrossRef] [PubMed]

196. Goethel, A.; Croitoru, K.; Philpott, D.J. The interplay between microbes and the immune response in inflammatory bowel disease. J. Physiol. 2018. [CrossRef] [PubMed]

197. Coskun, M. Intestinal Epithelium in Inflammatory Bowel Disease. Front. Med. 2014, 1, 24. [CrossRef] [PubMed] 
198. Neurath, M.F. Current and emerging therapeutic targets for IBD. Nat. Rev. Gastroenterol. Hepatol. 2017, 14, 269-278. [CrossRef] [PubMed]

199. Holm, T.L.; Tornehave, D.; Søndergaard, H.; Kvist, P.H.; Sondergaard, B.-C.; Hansen, L.; Hermit, M.B.; Holgersen, K.; Vergo, S.; Frederiksen, K.S.; et al. Evaluating IL-21 as a Potential Therapeutic Target in Crohn's Disease. Gastroenterol. Res. Pract. 2018, 2018, 1-22. [CrossRef] [PubMed]

200. Hongyu Zhang, D.J.; Zhang, H.; Sun, J. Manipulation of Microbiome, a Promising Therapy for Inflammatory Bowel Diseases. J. Clin. Cell. Immunol. 2014, 5, 1-10. [CrossRef]

201. Hansen, J.J.; Sartor, R.B. Therapeutic Manipulation of the Microbiome in IBD: Current Results and Future Approaches. Curr. Treat. Options Gastroenterol. 2015, 13, 105-120. [CrossRef] [PubMed]

202. Rodríguez-Nogales, A.; Algieri, F.; Garrido-Mesa, J.; Vezza, T.; Utrilla, M.P.; Chueca, N.; Fernández-Caballero, J.A.; García, F.; Rodríguez-Cabezas, M.E.; Gálvez, J. The Administration of Escherichia coli Nissle 1917 Ameliorates Development of DSS-Induced Colitis in Mice. Front. Pharmacol. 2018, 9, 468. [CrossRef] [PubMed]

203. Le, B.; Yang, S.H. Efficacy of Lactobacillus plantarum in prevention of inflammatory bowel disease. Toxicol. Rep. 2018, 5, 314-317. [CrossRef] [PubMed]

204. Chang, J.; Leong, R.W.; Wasinger, V.C.; Ip, M.; Yang, M.; Phan, T.G. Impaired Intestinal Permeability Contributes to Ongoing Bowel Symptoms in Patients With Inflammatory Bowel Disease and Mucosal Healing. Gastroenterology 2017, 153, 723-731. [CrossRef] [PubMed]

205. Ulluwishewa, D.; Anderson, R.C.; McNabb, W.C.; Moughan, P.J.; Wells, J.M.; Roy, N.C. Regulation of Tight Junction Permeability by Intestinal Bacteria and Dietary Components. J. Nutr. 2011, 141, 769-776. [CrossRef] [PubMed]

206. Pott, J.; Maloy, K.J. Epithelial autophagy controls chronic colitis by reducing TNF-induced apoptosis. Autophagy 2018, 1-2. [CrossRef] [PubMed]

207. Hevia, A.; Milani, C.; López, P.; Cuervo, A.; Arboleya, S.; Duranti, S.; Turroni, F.; González, S.; Suárez, A.; Gueimonde, M.; et al. Intestinal dysbiosis associated with systemic lupus erythematosus. MBio 2014, 5, e01548-14. [CrossRef] [PubMed]

208. Yacoub, R.; Jacob, A.; Wlaschin, J.; McGregor, M.; Quigg, R.J.; Alexander, J.J. Lupus: The microbiome angle. Immunobiology 2017. [CrossRef] [PubMed]

209. Luo, X.M.; Edwards, M.R.; Mu, Q.; Yu, Y.; Vieson, M.D.; Reilly, C.M.; Ahmed, S.A.; Bankole, A.A. Gut Microbiota in Human Systemic Lupus Erythematosus and a Mouse Model of Lupus. Appl. Environ. Microbiol. 2017, 84, e02288-17. [CrossRef] [PubMed]

210. Mu, Q.; Tavella, V.J.; Kirby, J.L.; Cecere, T.E.; Chung, M.; Lee, J.; Li, S.; Ahmed, S.A.; Eden, K.; Allen, I.C.; et al. Antibiotics ameliorate lupus-like symptoms in mice. Sci. Rep. 2017, 7, 13675. [CrossRef] [PubMed]

211. Quadro, L.; Gamble, M.V.; Vogel, S.; Lima, A.A.M.; Piantedosi, R.; Moore, S.R.; Colantuoni, V.; Gottesman, M.E.; Guerrant, R.L.; Blaner, W.S. Retinol and Retinol-Binding Protein: Gut Integrity and Circulating Immunoglobulins. J. Infect. Dis. 2000, 182, S97-S102. [CrossRef] [PubMed]

212. Lima, A.A.M.; Soares, A.M.; Lima, N.L.; Mota, R.M.S.; Maciel, B.L.L.; Kvalsund, M.P.; Barrett, L.J.; Fitzgerald, R.P.; Blaner, W.S.; Guerrant, R.L. Effects of vitamin A supplementation on intestinal barrier function, growth, total parasitic, and specific Giardia spp infections in Brazilian children: A prospective randomized, double-blind, placebo-controlled trial. J. Pediatr. Gastroenterol. Nutr. 2010, 50, 309-315. [CrossRef] [PubMed]

213. Davis-Richardson, A.G.; Ardissone, A.N.; Dias, R.; Simell, V.; Leonard, M.T.; Kemppainen, K.M.; Drew, J.C.; Schatz, D.; Atkinson, M.A.; Kolaczkowski, B.; et al. Bacteroides dorei dominates gut microbiome prior to autoimmunity in Finnish children at high risk for type 1 diabetes. Front. Microbiol. 2014, 5, 678. [CrossRef] [PubMed]

214. De Oliveira, G.L.V. Dysbiosis in autoimmune diseases: Alterations of the gut microbiota in multiple sclerosis. In Proceedings of the 2nd International Conference on Autoimmunity, Frankfurt, Germany, 6-7 November 2017.

215. Hibberd, M.C.; Wu, M.; Rodionov, D.A.; Li, X.; Cheng, J.; Griffin, N.W.; Barratt, M.J.; Giannone, R.J.; Hettich, R.L.; Osterman, A.L.; et al. The effects of micronutrient deficiencies on bacterial species from the human gut microbiota. Sci. Transl. Med. 2017, 9, eaal4069. [CrossRef] [PubMed]

216. Hatakeyama, S.; Ishida, K.; Takeda, Y. Changes in cell characteristics due to retinoic acid; specifically, a decrease in the expression of claudin- 1 and increase in claudin- 4 within tight junctions in stratified oral keratinocytes. J. Periodontal Res. 2010, 45, 207-215. [CrossRef] [PubMed] 
217. Molina-Jijón, E.; Rodríguez-Muñoz, R.; Namorado, M. del C.; Bautista-García, P.; Medina-Campos, O.N.; Pedraza-Chaverri, J.; Reyes, J.L. All-trans retinoic acid prevents oxidative stress-induced loss of renal tight junction proteins in type-1 diabetic model. J. Nutr. Biochem. 2015, 26, 441-454. [CrossRef] [PubMed]

218. Retana, C.; Sanchez, E.; Perez-Lopez, A.; Cruz, A.; Lagunas, J.; Cruz, C.; Vital, S.; Reyes, J.L. Alterations of Intercellular Junctions in Peritoneal Mesothelial Cells from Patients Undergoing Dialysis: Effect of Retinoic Acid. Perit. Dial. Int. 2015, 35, 275-287. [CrossRef] [PubMed]

219. Kubota, H.; Chiba, H.; Takakuwa, Y.; Osanai, M.; Tobioka, H.; Kohama, G.-I.; Mori, M.; Sawada, N. Retinoid X Receptor $\alpha$ and Retinoic Acid Receptor $\gamma$ Mediate Expression of Genes Encoding Tight-Junction Proteins and Barrier Function in F9 Cells during Visceral Endodermal Differentiation. Exp. Cell Res. 2001, 263, 163-172. [CrossRef] [PubMed]

220. Osanai, M.; Nishikiori, N.; Murata, M.; Chiba, H.; Kojima, T.; Sawada, N. Cellular retinoic acid bioavailability determines epithelial integrity: Role of retinoic acid receptor alpha agonists in colitis. Mol. Pharmacol. 2007, 71, 250-258. [CrossRef] [PubMed]

221. Priyamvada, S.; Anbazhagan, A.N.; Gujral, T.; Borthakur, A.; Saksena, S.; Gill, R.K.; Alrefai, W.A.; Dudeja, P.K. All- trans -retinoic Acid Increases SLC26A3 DRA (Down-regulated in Adenoma) Expression in Intestinal Epithelial Cells via HNF-1 ß. J. Biol. Chem. 2015, 290, 15066-15077. [CrossRef] [PubMed]

222. Ding, X.; Li, D.; Li, M.; Wang, H.; He, Q.; Wang, Y.; Yu, H.; Tian, D.; Yu, Q. SLC26A3 (DRA) prevents TNF-alpha-induced barrier dysfunction and dextran sulfate sodium-induced acute colitis. Lab. Investig. 2018, 98, 462-476. [CrossRef] [PubMed]

223. Bonney, S.; Siegenthaler, J.A. Differential Effects of Retinoic Acid Concentrations in Regulating Blood-Brain Barrier Properties. Eneuro 2017, 4. [CrossRef] [PubMed]

224. Zhang, Z.; Li, J.; Zheng, W.; Zhao, G.; Zhang, H.; Wang, X.; Guo, Y.; Qin, C.; Shi, Y. Peripheral Lymphoid Volume Expansion and Maintenance Are Controlled by Gut Microbiota via RALDH+ Dendritic Cells. Immunity 2016, 44, 330-342. [CrossRef] [PubMed]

225. Stern, A.; Wold, A.E.; Östman, S. Neonatal Mucosal Immune Stimulation by Microbial Superantigen Improves the Tolerogenic Capacity of CD103+ Dendritic Cells. PLoS ONE 2013, 8, e75594. [CrossRef] [PubMed]

226. Wu, W.; Sun, M.; Chen, F.; Cao, A.T.; Liu, H.; Zhao, Y.; Huang, X.; Xiao, Y.; Yao, S.; Zhao, Q.; et al. Microbiota metabolite short-chain fatty acid acetate promotes intestinal IgA response to microbiota which is mediated by GPR43. Mucosal Immunol. 2017, 10, 946-956. [CrossRef] [PubMed]

227. Levy, M.; Thaiss, C.A.; Elinav, E. Metabolites: Messengers between the microbiota and the immune system. Genes Dev. 2016, 30, 1589-1597. [CrossRef] [PubMed]

228. Konieczna, P.; Groeger, D.; Ziegler, M.; Frei, R.; Ferstl, R.; Shanahan, F.M.; Quigley, E.M.; Kiely, B.; Akdis, C.A. Bifidobacterium infantis 35624 administration induces Foxp3 T regulatory cells in human peripheral blood: Potential role for myeloid and plasmacytoid dendritic cells. Gut 2011. [CrossRef]

229. Konieczna, P.; Ferstl, R.; Ziegler, M.; Frei, R.; Nehrbass, D.; Lauener, R.P.; Akdis, C.A.; O’Mahony, L. Immunomodulation by Bifidobacterium infantis 35624 in the Murine Lamina Propria Requires Retinoic Acid-Dependent and Independent Mechanisms. PLoS ONE 2013, 8, e62617. [CrossRef] [PubMed]

230. Kim, K.; Yang, J.-Y.; Kim, C.-H.; Cha, M.-N.H.-R.; Chang, S.-Y.; Chang, J.-H.; Ouk, J. Absence of Retinoic Acid Intestine by Disruption of Gut Flora in the Downregulation of Th17 Cells in the Small Downloaded from. J. Immunol. 2010. [CrossRef]

231. Bene, K.; Varga, Z.; Petrov, V.O.; Boyko, N.; Rajnavolgyi, E. Gut Microbiota Species Can Provoke both Inflammatory and Tolerogenic Immune Responses in Human Dendritic Cells Mediated by Retinoic Acid Receptor Alpha Ligation. Front. Immunol. 2017, 8, 427. [CrossRef] [PubMed]

232. Haileselassie, Y.; Navis, M.; Vu, N.; Qazi, K.R.; Rethi, B.; Sverremark-Ekström, E. Postbiotic Modulation of Retinoic Acid Imprinted Mucosal-like Dendritic Cells by Probiotic Lactobacillus reuteri 17938 In Vitro. Front. Immunol. 2016, 7, 96. [CrossRef] [PubMed]

233. Pittsley, R.A.; Yoder, F.W. Retinoid Hyperostosis-Skeletal Toxicity Associated with Long-Term Administration of 13-cis-Retinoic Acid for Refractory Ichthyosis. N. Engl. J. Med. 1983, 308, 1012-1014. [CrossRef] [PubMed]

234. Farinello, D.; Wozińska, M.; Lenti, E.; Genovese, L.; Bianchessi, S.; Migliori, E.; Sacchetti, N.; di Lillo, A.; Bertilaccio, M.T.S.; de Lalla, C.; et al. A retinoic acid-dependent stroma-leukemia crosstalk promotes chronic lymphocytic leukemia progression. Nat. Commun. 2018, 9, 1787. [CrossRef] [PubMed] 
235. Formelli, F.; Barua, A.B.; Olson, J.A. Bioactivities of $N$-(4-hydroxyphenyl) retinamide and retinoyl beta-glucuronide. FASEB J. 1996, 10, 1014-1024. [CrossRef] [PubMed]

236. Feng, L.; Hernandez, R.E.; Waxman, J.S.; Yelon, D.; Moens, C.B. Dhrs3a regulates retinoic acid biosynthesis through a feedback inhibition mechanism. Dev. Biol. 2010, 338, 1-14. [CrossRef] [PubMed]

(C) 2018 by the authors. Licensee MDPI, Basel, Switzerland. This article is an open access article distributed under the terms and conditions of the Creative Commons Attribution (CC BY) license (http://creativecommons.org/licenses/by/4.0/). 